\title{
Polonika wydawane w oficynach obszaru niemieckojęzycznego przykładem mobilności tekstów literackich w szesnastowiecznej Europie ${ }^{1}$
}

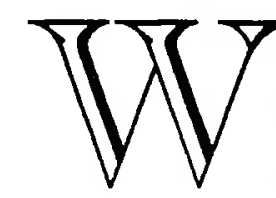
śród niezbadanych dotąd zjawisk w historii książki staropolskiej do ważniejszych należy problem edycji pism autorów polskich za granica. Traktując książkę jako narzędzie komunikacji międzyludzkiej, trudno nie zadać sobie pytania o rolę zagranicznych oficyn wydawniczych w dopelnianiu repertuaru wydawniczego drukarni polskich. $\mathrm{Z}$ drugiej strony istotne jest pytanie o role poloników w życiu kulturalnym Europy XVI w. Należy więc wyjaśnić, w jakim stopniu emanacją aktywności, a równocześnie atrakcyjności kultury polskiej, były zagraniczne publikacje poloników. Tak szeroki zakres badań podyktowany jest przekonaniem o tym, że nie można się ograniczyć wyłącznie do kwestii stosunków wydawniczych, ale należy rozpatrywać je w całym bogactwie problematyki składającej się na obraz epoki XVI w. Książka jest tutaj zmaterializowanym wyrazem myśli ludzkiej, na której powstanie złożyło się wiele czynników, m.in. humanizm; renesansowy prąd artystyczno-literacki stanowiący zespół wszystkich prac, w tym literackich, a także działalność twórcza autorów, teoretyków i ludzi wspóttworzących dzieła (wydawców-drukarzy, ilustratorów, nakładców, thumaczy, komentatorów, redaktorów itp.) oraz osób i instytucji, które do powstania i publikacji dzieła się przyczyniły, tzn. mecenasów lub instytucji sprawczych; ${ }^{2}$ reformacja i kontrreformacja oraz uwarunkowania polityczne. Owe czynniki stanowiły w naturalny sposób płaszczyznę integracji środowiskowej - nie tylko w skali danego ośrodka intelektualnego, ale takze na obszarze poszczególnych państw i całej Europy. Książa była jednym $z$ narzędzi owej integracji.

Tematyka ta nie doczekała się dotychczas pełnego opracowania w literaturze naukowej. Pewne informacje $z$ nią zwiazane znajdziemy w piśmiennictwie z zakresu historii książi, ${ }^{3}$ historii nauki, ${ }^{4}$ historii kultury, historii literatury ${ }^{6}$ oraz historii politycznej. ${ }^{7}$ Owe przyczynki w większości

Z Badan Nad Polskimi Księgozbiorami Historycznymi, 1. 18, Warszawa 1997 
przypadków poświęcone były związkom polsko-europejskim, a nie potraktowanym odrębnie stosunkom polsko-niemieckim.

Jest to o tyle usprawiedliwione, że mówiąc np. o europejskim ruchu wydawniczym, nie można pominąć faktu, że głównym jego komponentem w XVI w. było drukarstwo niemieckie. Jego działalności - w zakresie rozpowszechniania piśmiennictwa łacińskiego - nie można rozpatrywać wyłącznie w kategoriach regionalnych.

Najwięcej uwagi badanemu zjawisku poświęciła Alodia KaweckaGryczowa w artykule Rola drukarstwa polskiego $w$ dobie odrodzenia. ${ }^{8}$ Autorka zasygnalizowała kilka czynników mogących mieć wpływ na wędrówkę dzieł polskich do drukarń zagranicznych. Wskazała m.in. na ograniczone możliwości wytwórcze drukarzy polskich i niekorzystne zmiany w organizacji polskiego ruchu wydawniczego. W efekcie autor często wybierał oficynę zagraniczna gwarantującą mu dobry poziom wydania dzieła i możność prezentacji swojej twórczości na europejskim rynku czytelniczym. Wedhug A. Kaweckiej-Gryczowej większe dziela, oczywiście tacińskie moghy liczyc na adbiorców w catej Europie, znajdowaty wydawców w Bazylei, Kolonii. Wenecji. Drogi do tych ośrodków wyznaczahy najczęściej kierunki ideologiczne. ${ }^{9}$ Podkreślając wkład polskiego piśmiennictwa w ksztattowanie ogólnoludzkich wartości humanistycznych, autorka uwypukliła rolę związków wydawniczych z Bazylea. A. Kawecka-Gryczowa przeciwstawiła ów dorobek działalności ośrodków wydawniczych, które publikowały literaturę katolicką. Starając się przedstawić badane zjawisko w dynamice jego rozwoju, A. Kawecka-Gryczowa stwierdziła, że wzrost liczby wydań poloników nastapił w latach 60-tych i 80-tych wieku. Autorka wyjaśniała to wzmożoną walką ideologiczną: najpierw związaną z reformacją, a później $z$ kontrreformacja.

Z innych, ważnych czynników, które mogły wpłynąc na badane zjawisko, A. Kawecka-Gryczowa zwróciła uwagę na import ksiażki. Wobec ukierunkowania krajowego ruchu wydawniczego na publikację druków popularnych, literatury podręcznikowej i piśmiennictwa narodowego, potrzeby czytelnicze w zakresie literatury ambitniejszej - zwłaszcza naukowej - zaspokajała książka importowana.

Należy jednak stwierdzić, że zarówno artykuł A. Kaweckiej-Gryczowej jak $\mathrm{i}$ informacje zawarte $\mathrm{w}$ bogatym piśmiennictwie, poświęconym epoce XVI w., ${ }^{10}$ mogą shużyć jedynie jako punkt wyjścia do podjętych przeze mnie badań nad problematyką poloników niemieckich. Zajmuję się w nich historia ksiązki. Nie poddaje szczegótowej analizie tekstów poloników, 
ani nie oceniam treści dzieł $\mathrm{z}$ punktu widzenia historyczno-literackiego i naukowego. Interesuje mnie przede wszystkim konkretyzacja wydawnicza dzieła.

Podstawą moich badań była analiza bibliograficzna, zmierzająca do odtworzenia repertuaru wydawniczego oficyn $\mathrm{z}$ obszaru niemieckojęzycznego w zakresie produkcji poloników. " Jako datę wyjściową analizy przyjęto $1501 \mathrm{r}$., a jako datę zamykającą kwerendę $1600 \mathrm{r}^{12}$

Zasięg terytorialny badań wyznaczyły tereny niemieckojęzyczne, pozostające poza granicami Rzeczypospolitej. Pod pojęciem Rzeczypospolitej kryją się jej granice historyczne, obejmujące także terytoria zależne od Polski, tj. Inflanty i Prusy Książęce.

Pod pojęciem obszaru niemieckojęzycznego rozumie się natomiast tereny Niemiec, Austrii i niemieckojęzycznych kantonów Szwajcarii. Inaczej mówiąc chodzi o niemieckojęzyczne kraje Cesarstwa Rzymskiego Narodu Niemieckiego. Kryterium terytorialne było istotne dla zdefiniowania pojęcia autora polonikum w XVI w. Do twórców poloników zaliczono pisarzy, pochodzących $z$ terenów Rzeczypospolitej w jej ówczesnych, politycznych granicach lub ja zamieszkujących. Inne kryterium doboru to pochodzenie narodowe, a także - w przypadku autorów obcych - czasowy pobyt na terenie Rzeczypospolitej, o ile znalazł swoje odzwierciedlenie w twórczości danego autora. ${ }^{13}$ Decyduje tutaj miejsce powstania dzieła. Jeśli powstało na terenie Rzeczypospolitej to zaliczono je do poloników. Polonika będziemy dalej określać wydanymi na obszarze niemieckojęzycznym lub dla uproszczenia niemieckimi, bez względu na ich język

Zgodnie z definicją pracy autorskiej, przyjętą w Bibliografii Literatury Polskiej Nowy Korbut, kwerendą objęto zarówno utwory samoistne wydawniczo, jak i wydane w ramach większych całości oraz prace edytorskie, redaktorskie $\mathrm{i}$ thumaczenia.

Warto podkreślić, że analiza poloników wydanych w ramach większych całości winna określić, w jakim stopniu polonika $\mathrm{z}$ obszaru niemieckojęzycznego są wyrazem aktywności nie tyle poszczególnych autorów, co krajowych i obcych środowisk intelektualnych, wyznaniowych czy politycznych, z którymi autorzy byli powiązani.

Badając utwory autorów poloników, publikowane w ramach większych całości, można pokusić się o próbę wykrycia tych związków. Inaczej mówiąc należy odpowiedzieć sobie na pytanie, w jakim stopniu miały one charakter towarzyski, narodowościowy, intelektualny, wyznaniowy, polityczny, podyktowany jakimiś formami zależności spoleczno-materialnych (np. 1: tint. 
mecenas). Badania nad ilością i częstotliwością występowania podobnych powiazzań $w$ polonikach pozwalają na próbę rekonstrukcji procesu, który prowadził to tego, że druki ukazujące się w ciagu XVI w. stopniowo stawały się głównym świadectwem - obok korespondencji - owych kontaktów w skali micro, obejmującej najmniejsze grupy tworzone przez osoby należące np. do tego samego środowiska naukowego czy dworskiego, a także w skali macro, w której pisarze polscy jawią się jako aktywni członkowie europejskiej universitas. W przypadku braku świadectw na temat osobistych kontaktów między autorem polonikum, a wydawcą jego utworu, interesujące są kryteria doboru, jakimi kierował się wydawca danej pozycji, zamieszczając w nim polonikum. Ważne jest to, czy decydowała tutaj tylko tematyka polonikum, czy też czynniki wymienione uprzednio, a także sposób ujęcia tematu, doboru źródel, gatunek i forma literacka utworów dołączanych do dzieła podstawowego. Kolejna kwestia związana $\mathrm{z}$ utworami tego typu to próba odpowiedzi na pytanie, $w$ jakim stopniu wzbogacały one treśc całości, dopełniając podstawowe tezy naukowe, ideologiczne, czy polityczne formułowane przez autora dzieła głównego lub wydawcę zbioru pism, a w jakim stopniu miały podnieść rangę dzieła lub zbioru, prestiż jego autora, zareklamować je czytelnikowi.

Powyższe kwestie dotyczą głównie utworów opublikowanych $\mathrm{w}$ ramach poloników $\mathrm{z}$ obszaru niemieckojęzycznego. Utwory polskich autorów publikowano także przy dziełach pisarzy obcych. W ich przypadku pojawiają się nowe pytania, na które należałoby poszukać odpowiedzi. Naczelną kwestią jest próba rekonstrukcji drogi, jaką przebyły polonika, aby znaleźć zagranicznego wydawcę. Przy czym pojęcie drogi rozumiane jest tutaj jako zespół czynników geograficznych, środowiskowych, intelektualnych, wyznaniowych i politycznych wpływających w mniejszym lub większym stopniu na badane zjawisko. Będzie więc to pytanie o przyczyny, które zadecydowały o tym, że poszczególne utwory zostały w danym czasie - opublikowane na obszarze niemieckojęzycznym w ramach określonych druków obcych. Zbadanie tego zjawiska jest tym bardziej istotne, że w pewnym stopniu było ono niezależne od mechanizmów promocyjnych czy propagandowych, stosowanych przez polskie środowiska intelektualne, wyznaniowe i polityczne, majacych na celu przypominanie Europie o kulturalnej i politycznej roli Rzeczypospolitej i jej elit na kontynencie.

Odtworzony przy zastosowaniu powyższych kryteriów doboru repertuar wydawniczy jest niepelny wobec oczywistych luk w materiale bibliograficznym. Wydaje się jednak reprezentatywny dla badanego zjawiska. 
Ów repertuar poddano analizie strukturalno-typologicznej, prezentującej typy wydawnictw i ich przeznaczenie czytelnicze. Prze-prowadzono także badania analityczno-tematyczne i liczbowe, obrazujące skalę i dynamikę zjawiska, przy uwzględnieniu jego wewnętrznego zróżnicowania. Pozwoliło to na określenie typologii treściowej poloników, $\mathrm{z}$ uwzględnieniem zmian ilościowych $\mathrm{i}$ jakościowych $\mathrm{w}$ tym zakresie

Próbując określić stopień popularności poloników wśród wydawców z obszaru niemieckojezzycznego, zajęto się analizą ich wznowień. Dlatego też przedmiotem analizy tematycznej i liczbowej był także język publikacji. ze szczególnym uwzględnieniem ich niemieckojęzycznych thumaczeń.

Identycznymi badaniami objęto również polskie, tj. krajowe edycje tych samych prac, które wydawano na obszarze niemieckojęzycznym. Zmierzaly one do wyróżnienia poloników, stanowiących przedruki z edycji polskich. Po wtóre próbowano - przez analizę wznowień i thumaczeń poloników na język polski - wyodrębnić pozycje, cieszące się szczególnym zainteresowaniem wydawców i czytelników obu nacji. Wyróżniono również polonika, wydawane wyłącznie na obszarze niemieckojęzycznym $\mathrm{i}$ podjęto próbę wyjaśnienia tego zjawiska. Polonika $\mathrm{z}$ obszaru niemieckojęzycznego porównano także $\mathrm{z}$ ich edycjami, publikowanymi w innych krajach europejskich niż (umownie) Niemcy i Polska. Zbadano $w$ ten sposób kwestię $w$ jakim stopniu niemieccy wydawcy korzystali z europejskiej oferty wydawniczej, przygotowujac swoje edycje poloników

Przedmiotem badań były również motywacje autorów, decydujących się na wydanie dzieła $w$ oficynach obszaru niemieckojęzycznego. Przyczyn owych decyzji można było upatrywać w czynnikach subiektywnych, wiązących się $\mathrm{z}$ osobą samego autora, $\mathrm{np}$. $\mathrm{w}$ jego poglądach politycznych czy ideologicznych, rodzaju i źródle inspiracji twórczych (środowisko naukowo-literacko-wydawnicze, wspólnota wyznaniowa, frakcja polityczna), patriotyzmie, pragnieniu sławy literackiej czy naukowej itp. Istnialy także czynniki obiektywne, wpływające na decyzje wydawnicze pisarzy Były to m.in. ekonomiczne, polityczne i wyznaniowe uwarunkowania działalności polskiego i niemieckiego ruchu wydawniczego. Inne czynniki to międzynarodowe uznanie dotychczasowego dorobku twórczego autora: stopień adekwatności twórczości pisarza do standardów literackich i naukowych, jakim hołdowała $w$ danym czasie intelektualna Europa; pozycja społeczno-polityczna autora w skali kraju, ale i w skali ogólnoeuropejskiej; osobista zamożność autora lub stopień wsparcia finansowego ze strony 
mecenasa lub instytucji sprawczej itp. Interesujące było to, które $\mathrm{z}$ wymienionych czynników odegrały decydująca rolę.

Powyższe rozważania uzupehniono o próbę rekonstrukcji motywacji niemieckich wydawców poloników, tzn. thumaczy, nakładców, mecenasów, względnie instytucji sprawczych oraz samych drukarzy.

Wreszcie, przeprowadzono analizę ilościowego i jakościowego udziału poszczególnych ośrodków wydawniczych $\mathrm{z}$ obszaru niemieckojęzycznego w produkcji poloników. Pozwoliło to na określenie charakteru i stopnia natężenia związków autorów, nakładców oraz drukarzy z Polski z niemieckimi centrami księgarsko-wydawniczymi $\mathrm{w}$ poszczególnych okresach XVI w.

Przy tak szeroko zakreślonej problematyce badawczej zachodzi pytanie o źródła. Ze względów pragmatycznych - zdając sobie sprawę z ułomności tego rozwiazania - kwerendę źródłową ograniczono do bibliograficznych materiałów publikowanych i kartkowego Centralnego Katalogu Poloników XVI w. Biblioteki Narodowej. Pozwoliło to na opracowanie uporządkowanej alfabetycznie (według haseł autorskich lub tytułowych) kartoteki poloników z obszaru niemieckojęzycznego. Znalazły się $\mathrm{w}$ niej 2234 pozycje. Wykorzystano ją do wszelkich analiz liczbowych, prezentowanych $\mathrm{w}$ tekście niniejszego opracowania. Posłużła również do badań nad częstotliwością wydań poloników.

Wychodząc $\mathrm{z}$ założenia, że podstawowym źródłem badawczym w przypadku analizy dróg przepływu tekstów, motywacji autorów, współautorów i wydawców poloników, powinna być sama książka, w 200 przypadkach przebadano konkretne egzemplarze druków. Wszystkie wykorzystane $\mathrm{w}$ ten sposób pozycje są oznaczone $\mathrm{w}$ tekście przez cytatę sygnatury bibliotecznej Biblioteki Narodowej w Warszawie (BN) względnie Biblioteki Uniwersyteckiej w Warszawie (BUW).

Tytuły cytowanych w tekście wydawnictw podano $w$ formie występującej w Bibliografii Literatury Polskiej Nowy Korbut. W przypadku gdy nie zostały tam odnotowane, cytowano je za innymi polskimi względnie obcymi bibliografiami, stosując odpowiednie skróty. Nazwiska i imiona niemieckich drukarzy podano $\mathrm{w}$ formie stosowanej przez Josefa Benzinga, Die Buchdrucker des 16. und 17. Jahrhunderts im deutschen Sprachgebiet, Wiesbaden 1963. 


\section{Polonika z obszaru niemieckojęzycznego w liczbach.}

\section{Ogólne dane liczbowe.}

Zjawisko publikacji poloników na obszarze niemieckojęzycznym należy rozpatrywać w szerszym spektrum. Pozwoli to na zdefiniowanie jego skali i rzeczywistego znaczenia. W pierwszym rzędzie należy zwrócić uwagę na wielkość szesnastowiecznej, niemieckiej produkcji wydawniczej W XVI w. co najmniej 999 drukarzy działało w ok. 140 miejscowościach niemieckich. $^{14}$ Opublikowali oni od 130.000 do 150.000 jednostek bibliograficznych. ${ }^{15}$ Niemiecka publiczność czytelnicza mogła obejmować od 400.000 do 800.000 osób. Po prostu obliczono, że pisma luterańskie a więc w dużej części w języku niemieckim - dotarły do 170.000-250.000 niemieckich rodzin. ${ }^{16}$

W rzeczywistości publiczność czytelnicza była na tym terenie znacznie większa. Należy bowiem uwzględnić także czytelników łacińsko-języcznych, czasowo przebywających w Niemczech. Trzeba także pamiętać, że niemieckie oficyny wydawnicze zaopatrywały w książki całą Europę.

Udział poloników w tak ogromnej produkcji wydawniczej był znikomy Wynosił ok. 1050 samoistnych wydawniczo druków oraz co najmniej 1184 utwory, opublikowane w ramach większych całości. W porównaniu z wysokością polskiej produkcji wydawniczej, była to duża liczba. Wedlug Kazimierza Piekarskiego w szesnastowiecznej Polsce było ok. 3,5 miliona egzemplarzy książek, nie wliczając w to druków importowanych. ${ }^{17}$

Przyjmując za A. Kawecką-Gryczową wysokość przeciętnego nakladu w liczbie 500 egzemplarzy, można szacować polską produkcję wydawniczą na ok. 6.000 publikacji. ${ }^{18}$ Wedhug samej A. Kaweckiej-Gryczowej, nie licząc krajów lennych i Sląska, polskie oficyny wydały ok. 4.168 pozycji (ok. 1.668 tytułów w pierwszej połowie XVI w., a w drugiej ok. 2.500)." Do tej liczby według A. Kaweckiej-Gryczowej należałoby dodać ok. 724 tytuły wyttoczone za granica. ${ }^{20}$

W ten sposób polski repertuar wydawniczy można szacować na ok. 5.000-6.000 tytułów dzieł. Dokładniejsze dane zawiera praca Marii Czarnowskiej Ilościowy rozwój polskiego ruchu wydonniczego. 1501-196.5.21 $\mathrm{Na}$ ich podstawie można obliczyć, że w pierwszej połowie XVI w funkcjonowało w Polsce ok. 2.485 tytułów publikacji, a w drugiej ok. 5.471. Ogółem daje to liczbę ok. 7.985 tytułów. Należy przy tym zaznaczyć, że obliczenia M. Czamowskiej obejmuia także polonika wy dan za granicą. ${ }^{22}$ Można więe sądzic, ze liczba szesnastowiecznych polo 
wynosiła od 7.000 do 8.000 tytułów. Liczba ta jest nieporównywalna, a raczej nieproporcjonalna (nieprzystająca) w stosunku do wysokości niemieckiej produkcji wydawniczej. Jednak należy zaznaczyć, że jest znacznie zaniżona. Badania M. Czarnowskiej są wysoce niekompletne i wymagają aktualizacji. Nie ulega jednak wątpliwości, że różnica między wielkością polskiej i niemieckiej produkcji wydawniczej była wynikiem poziomu rozwoju drukarstwa polskiego. Wystarczy przypomnieć, że do $1580 \mathrm{r}$. działały w Polsce tylko 64 drukarnie. Z ośrodków drukarskich jedynie Kraków mógł zasługiwać na miano prawdziwego centrum wydawniczego.

Mniejszy wpływ na wysokość produkcji wydawniczej miała wielkość polskiej publiczności czytelniczej. Oblicza się ją na ok. 750.000 potencjalnych czytelników. $^{23}$ Często czytelnik zaspokajał swoje potrzeby przez lekturę wydawnictw zagranicznych. Dlatego, że duża część polskiej produkcji wydawniczej nie odpowiadała estetycznym i poznawczym wymaganiom osób, dysponujących kompetencjami czytelniczymi, porównywalnymi ze standardami elit europejskich. ${ }^{24} Z$ kolei polscy intelektualiści nie zawsze znajdowali partnerów w drukarzach, działajacych na terenie Rzeczypospolitej, ani odpowiednio dużej grupy czytelników, przygotowanej do odbioru ich twórczości.

2. Samoistne wydawniczo polonika w liczbach.

Polonika tego typu liczyły ok. 1050 druków (ok. 310 ukazało się w pierwszej połowie XVI w., a ok. $740 \mathrm{w}$ drugiej). ${ }^{25} \mathrm{Na}$ podstawie danych M. Czarnowskiej można obliczyć, że publikacje z niemieckiego obszaru językowego stanowiły ok. $13 \%$ całej, krajowej i zagranicznej, produkcji poloników. W obu połowach XVI w. ów udział również kształtował się w granicach $13 \%$ (ok. $12.7 \%$ w pierwszej połowie XVI w. i ok. $13.4 \%$ w drugiej). Stosunek między liczbą druków wydanych w poszczególnych dziesięcioleciach XVI w. na obszarze niemieckojęzycznym, a ogólną liczbą poloników, przedstawia tabela nr 1 . 


\begin{tabular}{|c|r|r|r|}
\hline Lata & $\begin{array}{c}\text { Ogólna } \\
\text { liczba } \\
\text { poloników }\end{array}$ & $\begin{array}{c}\text { Liczba poloników } \\
\text { opublikowanych na } \\
\text { obszarze niemieckoję- } \\
\text { zycznym }\end{array}$ & $\begin{array}{c}\text { Procentowy } \\
\text { udział niemieckiej } \\
\text { produkcji w ogólnej } \\
\text { liczbie poloników }\end{array}$ \\
\hline $1501-1510$ & 237 & 78 & 33 \\
\hline $1511-1520$ & 510 & 88 & 17 \\
\hline $1521-1530$ & 515 & 20 & 4 \\
\hline $1531-1540$ & 625 & 45 & 13 \\
\hline $1541-1550$ & 525 & 76 & 24 \\
\hline $1551-1560$ & 703 & 164 & 16 \\
\hline $1561-1570$ & 869 & 138 & 11 \\
\hline $1571-1580$ & 993 & 144 & 8 \\
\hline $1581-1590$ & 1362 & 150 & 130 \\
\hline $1591-1600$ & 1544 & 130 & 7 \\
\hline
\end{tabular}

Tabela 1. Udzial druków z obszaru niemieckojęzycznego w ogólnej produkcji poloników.

Zaprezentowane w tabeli dane wskazują na zmienność procentowego udziału niemieckich druków w całej produkcji poloników. Wyrażną tendencję (spadkowa) obserwujemy tylko w latach 1511-1540. W drugiej połowie XVI w. ów udział kształtował się na poziomie kilkunastu procent (z wyjątkiem lat 1551-1560: $24 \%$ i 1591-1600: $8 \%$ \%). Do połowy XVI w. nie istniała wprost proporcjonalna zależność między wzrostem krajowej produkcji wydawniczej - rozumianej jako wyraz ogólnego rozwoju piśmiennictwa polskiego - a aktywnością autorów po-loników za granica. Natomiast w drugiej połowie XVI w. istniała pewna korelacja. Rozwojowi polskiego piśmiennictwa w tym okresie towarzyszył ogólny wzrost liczby edycji poloników na obszarze niemieckojęzycznym. Wyraził się przeciętną liczbą 130-140 poloników dla poszczególnych dziesięcioleci XVI w. Od tej przeciętnej odbiegały tylko lata 1551-1561 r., kiedy to na obszarze niemieckojęzycznym? ukazały się 164 polonika.

Największą grupę wśród poloników stanowity wydawnictwa o charakterze naukowym - ok. 370 tytułów (200 ukazało się w pierwszej połowie XVI w., a $170 \mathrm{w}$ drugiej) ${ }^{26}$ i piśmiennictwo religijne - ok 350 tytułów (60 ukazało się w pierwszej połowie XVI w., a $290 \mathrm{w}$ drugiej). ${ }^{27}$ Kolejną grupę tworzyto pismiennictwo historyczne i polityczno-pras 
łącznie ok. 205 tytułów (30 ukazało się w pierwszej połowie XVI w., a $175 \mathrm{w}$ drugiej). ${ }^{28}$ Powyższe zestawienie zamykała literatura piękna, zwykle poezja okolicznościowa i panegiryczna - ok. 125 tytułów (20 ukazało sie w pierwszej połowie XVI w., a $105 \mathrm{w}$ drugiej połowie).

Wysokość produkcji poloników z wymienionych grup tematycznych była odmienna w poszczególnych dziesięcioleciach XVI w. Można tutaj wyróżnić okresy wyraźnego wzrostu:

- dla piśmiennictwa naukowego było to pierwsze dwudziestolecie XVI w. i lata 1591-1600.

- w przypadku piśmiennictwa religijnego do wyjątkowych należały lata 1551-1560 r.

- największą liczbę poloników, reprezentujących piśmiennictwo historyczne i polityczno-prawne, wydano w latach 1571-1590.

Wskazują na to dane, przedstawione w tabeli nr 2.

\begin{tabular}{|c|r|r|r|r|}
\hline \multirow{2}{*}{ Lata } & \multicolumn{3}{|c|}{ Piśmiennictwo } & \multirow{2}{*}{$\begin{array}{c}\text { Literatura } \\
\text { piękna }\end{array}$} \\
\cline { 2 - 5 } & naukowe & religijne & $\begin{array}{c}\text { historyczne i poli- } \\
\text { tyczno-prawne }\end{array}$ & 5 \\
\hline $1501-1510$ & 57 & 16 & - & 9 \\
\hline $1511-1520$ & 61 & 11 & 7 & 2 \\
\hline $1521-1530$ & 13 & 4 & 3 & 5 \\
\hline $1531-1540$ & 25 & 11 & 7 & 24 \\
\hline $1541-1550$ & 40 & 20 & 21 & 20 \\
\hline $1551-1560$ & 37 & 82 & 28 & 22 \\
\hline $1561-1570$ & 39 & 51 & 46 & 16 \\
\hline $1571-1580$ & 21 & 55 & 51 & 19 \\
\hline $1581-1590$ & 25 & 58 & 27 & 27 \\
\hline $1591-1600$ & 45 & 40 & & 21 \\
\hline
\end{tabular}

Tabela 2. Produkcja poloników na obszarze niemieckojęzycznym w podziale na grupy tematyczne.

Jeśli chodzi o język poloników, publikowanych na obszarze niemieckojęzycznym, to największą grupę stanowiły druki łacińskojęzyczne (ponad $80 \%$ ). Polonika wydawano także w języku niemieckim, ${ }^{29}$ holenderskim, francuskim, ${ }^{30}$ kilka $\mathrm{w}$ greckim, ${ }^{31} \mathrm{~W}$ polskim, ${ }^{32}$ a takize węgierskim. ${ }^{3: 3}$ 
3. Polonika opublikowane w ramach większych całości - ogólne dane liczbowe.

$\mathrm{Na}$ podstawie spisów bibliograficznych i Centralnego Katalogu Poloników XVI w. Biblioteki Narodowej wyodrębniono 1184 poloników tego typu, ${ }^{34}$ autorstwa ok. 400 twórców. Z pierwszej połowy XVI w. pochodziło 277 utworów, natomiast z drugiej 907. W kolejnych dziesięcioleciach dane liczbowe kształtowały się następująco:

\begin{tabular}{|c|r|r|r|r|r|r|r|r|r|r|}
\hline Lata & $1501-$ & $1511-$ & $1521-$ & $1531-$ & $1541-$ & $1551-$ & $1561-$ & $1571-$ & $1581-$ & $1591-$ \\
& 1510 & 1520 & 1530 & 1540 & 1550 & 1560 & 1570 & 1580 & 1590 & 1600 \\
\hline $\begin{array}{c}\text { Liczba } \\
\text { utworów }\end{array}$ & 59 & 87 & 23 & 47 & 61 & 134 & 147 & 96 & 292 & 238 \\
\hline
\end{tabular}

Liczba utworów zależała od ilości poloników, w ramach których się ukazały. Najczęściej publikowano je w dwóch ostatnich dziesięcioleciach XVI w. Wiązało się to $\mathrm{z}$ publikacją kilku dużych zbiorów pism, w których znalazły się także polonika. Dużą rolę odegrały także publikacje dzieł wszystkich (opera omnia) polskich autorów. Wydawanie zbiorów pism było szczególnie popularne w piśmiennictwie historycznym. W nauce renesansowej historię świecką wiązano z historią religii i geografią. Obowiązywał tutaj schemat historiografii antycznej, zalecany w szesnastowiecznych traktatach z zakresu retoryki i stylistyki. Wymagał on, aby przy opisie kraju czy narodu, autor uwzględnił m.in. genezę państwa, opis fizyczny kraju, problematykę jego obronności, budownictwo, sprawy zdrowotne, ubiór i obyczaje mieszkańców, szkolnictwo, religię, oraz problematykę życia społeczno-politycznego państwa. ${ }^{35}$ Chcąc przedstawić w pełni tę problematykę, tworzono zbiory pism różnych autorów. Do wzrostu liczby poloników omawianego typu w ostatnim dwudziestoleciu XVI w., przyczyniła się także duża ilość publikacji dysertacji uniwersyteckich. ${ }^{36}$

W pierwszej połowie XVI w., wśód utworów dominowała literatura piękna (222 tytuły). Piśmiennictwo naukowe obejmowało 27 dzieł, piśmiennictwo o tematyce historycznej i polityczno-prawnej 17 , a religijnej 10 .

W drugiej połowie XVI w. również dominowała literatura piękna (370 utworów). Piśmiennictwo o tematyce historycznej i politycznoprawnej obejmowało 289 utworów, naukowe 140 dziel, a religijne 106. Ogólnie mówiąc przeważały prozatorskie i wierszowane utwory, tworzące tzw. literacka rame wydawnicza dzieła. Duża liczba nrac o tematyce historycznej i polityczno-prawnej. wydanych w dr... 
połowie XVI w., była wynikiem publikacji kilku zbiorów pism historycznych. Piśmiennictwo tego typu znalazło się także w zbiorach mów i zbiorach epistolografii politycznej. Problematyka politycznoprawną zajmowało się również szereg dysertacji uniwersyteckich.

Oprócz piśmiennictwa łacińskiego znalazły się tutaj także utwory w języku niemieckim (51), greckim (20) i polskim (15). ${ }^{37}$

Polonika, opublikowane $\mathrm{w}$ ramach większych całości, dzieliły się na dwie zasadnicze grupy:

- 718 utworów wydanych w ramach poloników;

- 466 utworów opublikowanych przy dziełach autorów obcych.

3.1. Utwory opublikowane w ramach poloników.

W XVI w. wydano co najmniej 718 poloników tego typu, ${ }^{38}$ autorstwa 300 pisarzy. Z pierwszej połowy XVI w. pochodziło 200 takich utworów, a $z$ drugiej 518 .

W poszczególnych dziesięcioleciach dane liczbowe kształtowały się następująco:

\begin{tabular}{|c|r|r|r|r|r|r|r|r|r|r|}
\hline Lata & $1501-$ & $1511-$ & $1521-$ & $1531-$ & $1541-$ & $1551-$ & $1561-$ & $1571-$ & $1581-$ & $1591-$ \\
& 1510 & 1520 & 1530 & 1540 & 1550 & 1560 & 1570 & 1580 & 1590 & 1600 \\
\hline $\begin{array}{c}\text { Liczba } \\
\text { utworów }\end{array}$ & 55 & 73 & 11 & 21 & 40 & 101 & 118 & 73 & 188 & 38 \\
\hline
\end{tabular}

Ok. 64\% stanowiła literatura piękna. ${ }^{39}$ Dominowały dedykacje, krótkie utwory poetyckie skierowane do czytelnika, autora, współautorów bądź mecenasa, epigramy poświęcone dziełu, epistolografia $z$ nim związana i przedmowy wydawnicze. Literatura przedmiotu zalicza piśmiennictwo tego typu do tzw. literackiej ramy wydawniczej druków. Utwory wykraczające poza funkcje, wyznaczone przez konwencję literackiej ramy wydawniczej, były rzadkie.

Kolejną grupe utworów tworzyło piśmiennictwo historyczne i polityczno-prawne. Zaliczono do niego 134 prace ( 8 pochodziło z pierwszej połowy XVI w., a $126 \mathrm{z}$ drugiej). W grupie dziel o charakterze polemiczno-teologicznym znalazło się 90 pozycji (4 pochodzity z pierwszej połowy XVI w., a 86 z drugiej). Powyższe zestawienie zamykało piśmiennictwo naukowe. Obejmowało 35 dzieł (9 pochodziło z pierwszej połowy XVI w., a 26 z drugiej). 
3.2. Polonika opublikowane przy dziełach autorów obcych.

Wyselekcjonowano co najmniej 466 utworów tego typu. ${ }^{40} 77$ ukazało się w pierwszej połowie XVI w., a 389 w drugiej. W poszczególnych dziesięcioleciach dane liczbowe kształtowały się następująco:

\begin{tabular}{|c|r|r|r|r|r|r|r|r|r|r|}
\hline Lata & $1501-$ & $1511-$ & $1521-$ & $1531-$ & $1541-$ & $1551-$ & $1561-$ & $1571-$ & $1581-$ & $1591-$ \\
& 1510 & 1520 & 1530 & 1540 & 1550 & 1550 & 1570 & 1580 & 1590 & 1600 \\
\hline $\begin{array}{c}\text { Liczba } \\
\text { utworów }\end{array}$ & 4 & 14 & 12 & 26 & 21 & 33 & 29 & 23 & 104 & 200 \\
\hline
\end{tabular}

Od lat trzydziestych XVI w. można było spotkać przeciętnie ponad dwadzieścia poloników, wydanych przy dzielach obcych autorów. Od tej średniej odbiegały dwa ostatnie dziesięciolecia XVI w. O przyczynach owej różnicy pisałem powyżej.

Wśród poloników tej grupy dominowało piśmiennictwo historyczne i polityczno-prawne. Obejmowało co najmniej 169 publikacji (6 pochodziło z pierwszej połowy XVI w., a 163 z drugiej). Kolejne miejsce zajmowało piśmiennictwo naukowe z 136 publikacjami (22 pochodziły z pierwszej połowy XVI w., a $114 \mathrm{z}$ drugiej). Do literatury pięknej można zaliczyć tylko 130 publikacji (40 pochodziło z pierwszej połowy XVI w., a $90 \mathrm{z}$ drugiej). Najmniejszą grupę stanowiło piśmiennictwo religijne. Obejmowało 31 publikacji ( 9 pochodziło z pierwszej połowy XVI w, a $22 \mathrm{z}$ drugiej).

Ze względu na znaczenie poloników tego typu - są one przeciez bezpośrednim świadectwem obecności polskiego piśmiennictwa w zyciu naukowym i literackim szesnastowiecznej Europy - warto przedstawic dokładniejsze dane dotyczące ich produkcji w poszczególnych dziesięcioleciach (zob. tabela nr 3).

\begin{tabular}{|c|r|r|r|r|}
\hline Lata & \multicolumn{3}{|c|}{ Piśmiennictwo } & \\
\cline { 2 - 5 } & naukowe & religijne & $\begin{array}{c}\text { historyczne } \\
\text { i polityczno- } \\
\text { prawne }\end{array}$ & $\begin{array}{c}\text { Literatura pięk- } \\
\text { na }\end{array}$ \\
\hline 1 & 2 & 3 & 4 & 5 \\
\hline $1501-1510$ & 1 & - & - & 3 \\
\hline $1511-1520$ & 3 & 1 & 1 & 11 \\
\hline $1521-1530$ & - & - & 1 & 11 \\
\hline $1531-1540$ & 9 & 4 & 2 & 2 \\
\hline $1541-1550$ & 9 & 4 & 2 & 2 \\
\hline
\end{tabular}




\begin{tabular}{|c|r|r|r|r|}
\hline \hline 1 & 2 & 3 & 4 & 5 \\
\hline $1551-1560$ & 8 & 3 & 9 & 13 \\
\hline $1561-1570$ & 9 & 6 & 8 & 6 \\
\hline $1571-1580$ & 9 & - & 7 & 7 \\
\hline $1581-1590$ & 23 & 3 & 61 & 17 \\
\hline $1591-1600$ & 65 & 10 & 78 & 4 \\
\hline
\end{tabular}

Tabela 3. Polonika opublikowane przy dzielach obcych autorów, $w$ podziale na grupy tematyczne.

Jeśli chodzi o charakterystykę językową tej grupy poloników, to $\mathrm{w}$ pierwszej połowie XVI w. odnotowujemy tylko jedną publikację $w$ języku niemieckim $i$ trzy $w$ greckim. Reszta to utwory łacińskie. W drugiej połowie XVI w. spisy bibliograficzne rejestruja, obok łacińskich, 11 utworów w języku niemieckim, 7 w polskim, 5 w greckim i jeden w holenderskim.

\section{Polonika wydawane w oficynach obszaru niemieckojęzycznego przykładem mobilności tekstów literackich w szesnastowiecznej Europie.}

1. Dzieła powstałe $\mathrm{w}$ Polsce, a wydane $\mathrm{w}$ oficynach $\mathrm{z}$ obszaru niemieckojęzycznego.

Co najmniej $80 \%$ wszystkich poloników w ogóle nie miało polskich edycji. Były wśród nich dzieła, które powstały na terenie Polski, ale autorzy opublikowali je poza granicami kraju. Tak było w przypadku części prac historiograficznych, ${ }^{41}$ religijnych $^{42}$ i naukowych. ${ }^{43}$

Niemiecki wydawca otrzymywał tekst dzieła bezpośrednio od autora lub za pośrednictwem redaktora pracy, osoby zaprzyjaźnionej z autorem, a udającej się za granicę, księgarzy niemieckich odwiedzających Polskę, przedstawicieli oficyn wydawniczych na targach książki, czy w końcu za pośrednictwem polskich nakładców. ${ }^{44}$ Czasem przesłanie tekstu książki do oficyny wydawniczej łączyło $w$ sobie kilka $z$ wymienionych form pośrednictwa.

Charakterystyczna była w tej grupie poloników chęć autorów do kontrolowania procesu wydawniczego ich dziel. ${ }^{45}$ Autor lub redaktor starał się czuwać nad poprawnościa druku, wprowadzał własne poprawki w tekście utworu przygotowując jego następne wydania. 
Najlejpiej te procesy obrazuja kolejne wydania De origine et rebus gestis Polonorum libri XXX Marcina Kromera, Confessio fidei catholicae Christiana Stanisława Hozjusza. ${ }^{46}$

2. Polonika opublikowane $\mathrm{w}$ oficynach obszaru niemieckojęzycznego na podstawie ich polskich edycji.

Część niemieckich wydań poloników poprzedzona była edycjami tych samych dzieł w oficynach polskich (ok. 160 tytułów). Interesujące jest, czy istniały różnice między tymi publikacjami. Przy porównaniu niemieckich i polskich edycji poloników zwraca uwagę fakt, że w przypadku druków z pierwszej połowy XVI w., a zwłaszcza z pierwszego dwudziestolecia, różnice były nieznaczne. Charakterystyczne jest to, że edycje polskie i niemieckie różnią się w większości przypadków tylko adresem wydawniczym i szczegółami typograficznymi. Co więcej, wydania krakowskie wydają się niekiedy staranniejsze od niemieckich. Część edycji niemieckich i polskich różniła się wyposażeniem ilustracyjnym druków i pewnymi zmianami redakcyjnymi. np. w brzmieniu tytułów. Przykładem jest podręcznik logiki jana z Głogowa (Exercitium veteris artis). Argumentum in librum Porphyrii peripatetici isagogicum in kathegorias Aristotelis. Został wydany w $1504 \mathrm{r}$ (dwukrotnie: w drukarni Jana Hallera ${ }^{47}$ i tamże przy udziale Kaspara Hochfedera $^{48}$ ) oraz w 1516 r. również drukiem J. Hallera. ${ }^{49}$ Wymienione edycje różniły się tylko w wyposażeniu ilustracyjnym druków. Wydanie J. Hallera z 1504 r. posiadało na odwrocie karty tytułowej herby Królestwa Polskiego, Wielkiego Księstwa Litewskiego i miasta Krakowa. ${ }^{50}$ Krakowskie wydanie z 1516 r. było pozbawione herbow W wydaniu niemieckim z 1517 r., opublikowanym w Strasburgu w oficynie Johanna Knobloucha, herby w ogóle nie występuja. ${ }^{31}$ Herby te pojawiały się w niemieckich edycjach poloników, które ukazywały się nakładem Marka Scharffenberga.

Wspomniane, strasburskie wydanie Exercitium veteris artis Jana z Głogowa miało zmieniony tytuł w stosunku do edycji krakowshich. W odróżnieniu od wydań krakowskich tytuły cechował się zwięzłoscią treści. Wiersz Ottomara Nachtigala, brak herbów, zmiany w tytule oraz adres wydawniczy są jedynymi elementami odróżniającymi edycję strasburską od krakowskich. Treść dzieła. wraz z przedmowami wyr: 
określającymi jego przeznaczenie dla studentów Akademii Krakowskiej, zostały przedrukowane przez $\mathrm{J}$. Knobloucha w niezmienionym kształcie.

Naturalnie, niemieccy drukarze uwzględniali w swoich edycjach poloników rysunki i wykresy ilustrujące tekst dzieła. Tak było m.in. w przypadku strasburskiej edycji J. Knobloucha Introductorium compendiosum in tractatum Sphaerae...Joannis de Sacrobusto z $1518 \mathrm{r}^{52}$ Opracował je Jan z Głogowa - na wyraźne życzenie i nalegania J. Hallera, jak podkreślał $w$ swojej przedmowie krakowski uczony. ${ }^{53}$ Introductorium... miało służyć jako podręcznik dla studentów Akademii Krakowskiej. Następna, krakowska edycja książki, uzupełniona o tablicę declinationis solis, ukazała się nakładem J. Hallera i drukiem Floriana Unglera w $1513 \mathrm{r}^{54}$ Właśnie ta edycja stanowiła podstawę do wydania strasburskiego J. Knobloucha $\mathrm{z} 1518 \mathrm{r}^{55}$ Obie edycje były prawie identyczne - $z$ wyjątkiem pominięcia przez J. Knobloucha herbu miasta Krakowa, występującego w wydaniu krakowskim. Zawierały ten sam wiersz do czytelnika, przedmowy i tekst właściwy, a także rysunek wyobrażający sferę niebieska.

Można wymienić jeszcze co najmniej kilkadziesiąt niemieckich edycji poloników, które stanowity dosyć dokładne, wierne przedruki $\mathrm{z}$ wydań polskich. Zwykle pochodzity z pierwszej połowy XVI w. ${ }^{56}$ Wśród poloników $z$ drugiej połowy wieku również spotykamy podobne edycje dziel, zazwyczaj charakteryzujących się małą broszurową objętością. $^{57}$ Do nielicznych wyjątków należało obszerne dzieło Decisiones... de rebus in sacro auditorio Lithuanico Piotra Rojzjusza, opublikowane nakładem Sigismunda Feyerabenda w 1570 r. przy Decisiones Sacri Senatus Pedemontani ab Octaviano Cacherano... colectae. ${ }^{58}$ Edycja ta różni się tylko nieznacznie od krakowskiego pierwodruku z $1563 \mathrm{r}^{59}$, ale są to zmiany charakterystyczne. Polegaja na innym sformułowaniu tytułu - w wydaniu niemieckim zawiera tylko najistotniejsze informacje, dotyczące treści dzieła - dodaniu na karcie tytułowej drzeworytowej ilustracji przedstawiającej obrady sądu, pominięciu komentarzy na marginesach oraz na poprawkach błędów w tekście, występujących w wydaniu krakowskim

$\mathrm{Z}$ biegiem czasu niemieckie i polskie edycje poszczególnych utworów zaczęły się coraz bardziej różnić. Warto tutaj zwrócić uwagę na pierwsze niemieckie wydanie Oratio in funere... Sigismundi...regis M. Kromera. Polskie wydanie mowy ukazało się w $1548 \mathrm{r}^{60}$ Pierwsza, niemiecka edycja Oralio... byla dzielem joannesa Cochiaeusa, ktory ją wydał wraz 
z mowa Samuela Maciejowskiego w Viktorstift koło Moguncji (w oficynie Franza Behema w 1550 r.) w zbiorze De Sigismundo Primo Rege Poloniae...duo panegyrici funebres. ${ }^{61}$ Właśnie temu wydaniu Oratio... warto poświęcić szczególną uwage. ${ }^{62} \mathrm{~J}$. Cochlaeus w dedykacji do swego antistesa Ioannesa Dubraviusa wspominał, że $w$ jego posiadaniu znalazło się kilka pism poświęconych Zygmuntowi Staremu, opublikowanych przez krakowskie oficyny drukarskie. Spośród nich za najbardziej godne ponownego wydania uznal mowy M. Kromera i Sermo habitus...in funere...Sigismundi Primi S. Maciejowskiego. J. Cochlaeus połączył oba utwory i wydał, opatrując edycję wspomnianą dedykacją. Oczywiście były tutaj zmiany redakcyjne $w$ stosunku do krakowskich publikacji obu utworów. W wydaniu niemieckim przy obu mowach występowały noty marginalne, odnoszące się do treści dzieła, których nie było w wydaniach krakowskich. Wydanie niemieckie pozbawione było ilustracji, występujących przy edycjach krakowskich Do utworu S. Maciejowskiego dołączone było w wydaniu krakowskim, a potem niemieckim Sigismundi I epitafium Jana Dantyszka.

Jest to istotne, gdyż M. Kromer wykorzystywał później wiersz J. Dantyszka, dołączając go do kolejnych wydań swojego (Oratio in funere...Sigismundi...regis, ${ }^{64}$ zamieszczanych przy De origine et rehus. gestis Polonorum libri $X X X^{65}$ Komponując treść De origine... mógł się więc M. Kromer opierać także na zawartości wydawnictwa J. Cochlaeusa. Owa kompozycja - składały się na nią trzy elementy Oratio in funere..., czterowiersz M. Kromera oraz epitafium J. Dantyszka - była powtarzana w następnych wznowieniach De origine... Podstawą dla kolejnych edycji Oratio in funere... było więc wydanie niemiechie z 1550 r. Świadczą o tym także wspomniane marginalia, występujące, za wydaniem mogunckim, w późniejszych edycjach mowy.

$\mathrm{Z}$ punktu widzenia pochodzenia niemieckich edycji poloników do ciekawszych utworów należy Alberto a Lasco...exhortatio ad milite's in expeditione Moldavica, cum Jacobum Basilicum Despotam in Reginum introduceret... 1561. Pierwsze wydanie mowy Olbrachta Laskiego ukazaio się w Krakowie w 1567 r. Byla dodatkiem do historii Węgie! Chronologia de rebus Hungaricis, autorstwa dworzanina O. Łaskiego Abrahama Bakschaya. Jak można sądzić, publikację finansował sam O. Łaski. ${ }^{66}$ Aby wyjaśnić dzieje ponownych edycji zarówno mowy O. Laskiego jak i Chronologia de rebus Hungaricis A. Bakschaya, nalezy wspomnieć o tym. że O. Laski byl jednym z najgorliwszych stronni" 
Habsburgów. Jako taki utrzymywał kontakt z Andrzejem Dudyczem. W tym czasie $\mathrm{O}$. Łaski związany był także ze środowiskiem kalwinistów polskich - przeszedł na katolicyzm dopiero w 1569 r. Wyrazem owych związków był wiersz pochwalny Andrzeja Trzecieskiego mł. na Chronologia de rebus Hungaricis A. Bakschaya, zamieszczony w jej krakowskim wydaniu. Można więc sądzić, że nie tylko treść omawianej publikacji, ale także splot czynników natury politycznowyznaniowo-towarzyskiej spowodował, że krakowskie wydanie Chronologia... bardzo szybko dotarło do nadwornego dziejopisa Rudolfa II, węgierskiego humanisty Joannesa Sambucusa (wł. Zsámboki János). ${ }^{67}$ Ten wydał $\mathrm{w}$ całości publikację krakowską ${ }^{68}$ w ramach Rerum Ungaricarum decades quatuor cum dimidia Antonio Bonfiniego, umieszczając ją na końcu dzieła po historii Attyli Filipa Kallimacha. ${ }^{69}$ Warto dodać, że w tej redakcji Rerum Ungaricarum... znalazł się także wiersz Karla Utenhove'a mł., poświęcony J. Sambucusowi. K. Utenhove'a mł. łączyły szczególne związki z rodziną Laskich. Jego ojciec Karol st. był towarzyszem Jana Laskiego ml. w czasie pobytu w Bazylei. $\mathrm{Z}$ kolei stryj Karola $\mathrm{ml}$. John Utenhove był jednym $\mathrm{z}$ najbliższych współpracowników J. Łaskiego mł. Sam Karol mł. był zaprzyjaźniony m.in. z A. Dudyczem. Ponieważ omawiana edycja dzieła A. Bonfiniego zawierała także wiersze innego znajomego A. Dudycza, Philippusa Gandavensisa, nie wykluczony jest jakiś udział A. Dudycza w przedsięwzięciu wydawniczym J. Sambucusa. Ten ostatni nic o tym nie wspomina, wymieniając natomiast w dedykacji do Maksymiliana II Krzysztofa Trecego, jako osobę pośrednicząca w jego kontaktach z Johannem Oporinusem. Następne wydanie Rerum Ungaricarum... ukazało się w $1581 \mathrm{r}$. we Frankfurcie nad Menem w oficynie Andreasa Wechela. ${ }^{70}$ Było to wydanie zmienione $w$ stosunku do poprzedniego. A. Wechel zachował tylko te elementy $z$ poprzedniej edycji, które miały merytoryczny związek z głównym tematem dzieła. Oprócz wprowadzenia poprawek, wydawca usunął wszystkie utwory towarzyszqce: wiersze $\mathrm{K}$. Utenhove'a i Ph. Gandavensisa, a w przypadku Chronologia de rebus Hungaricis A. Bakschaya, utwory A. Trzecieskiego mł., J. Łaskiego, Jana ze Swidnicy i Adama Schroetera. Z polonikow wydawca zachował tylko dedykację A. Bakschaya do O. Laskiego, mowę O. Łaskiego i Chronologia... oraz dzieło F. Kallimacha. Omawiana edycja poloników w Rerum Ungaricarum decades quatuor cum dimidia... z 1581 r. jest przykładem nowego opracowania redakcyjnego dzieł przez 
ich niemieckich wydawców. Ze zjawiskiem tym spotykamy się głównie wśród poloników publikowanych w ramach większych całości. Tak było w przypadku Chronica Polonorum Macieja z Miechowa zamieszczonej w zbiorze Polonicae historiae corpus Joannesa Pistoriusa. ${ }^{71}$ Wydanie J. Pistoriusa nie różniło się znacznie od krakowskiej edycji kroniki z 1521 r., z której twórca Polonicae historiae corpus korzystał. ${ }^{72}$ W swojej redakcji J. Pistorius, zmieniając nieco kompozycyjny układ tekstu dzieła, pominął jego zdaniem elementy nieistotne: erratę $z$ listem Hieronima Wietora do czytelnika i elementy dzieła nie mieszczące się w przyjętej konwencji zbioru. W tym drugim przypadku chodzi o pominięcie ilustracji wraz $z$ towarzyszącymi im epigramami. Pozostałe części krakowskiej publikacji, tj. dedykacje, przedmowy wydawnicze, list autora do Andrzeja Krzyckiego $z$ epigramem tego ostatniego, samą kronike Macieja $\mathrm{z}$ Miechowa oraz towarzyszące jej dzieła Jodoka Ludwika Decjusza znalazły się w Polonicae historiae corpus bez zmian w treści, z notami na marginesach włącznie. Niemiecki wydawca w odróżnieniu od edycji krakowskiej - zaznaczał natomiast te fragmenty tekstu kroniki Miechowity, które miały charakter cytatów, np. dwuwiersz Grzegorza z Sanoka. ${ }^{73}$

Ponadto J. Pistorius poprawił błędy edycji krakowskiej, powstałe w wyniku pomyłki w liczbowaniu rozdziałów. ${ }^{74} \mathrm{Z}$ drugiej strony także wydanie J. Pistoriusa zawierało błąd. Wynikał on zapewne $z$ tego, że autor zbioru musiał korzystać ze zdefektowanego egzemplarza krakowskiego wydania kroniki Macieja z Miechowa. Dlatego w Polonicae historiae corpus nie został przedrukowany w całości końcowy fragment utworu J. L. Decjusza De Jagellonum familia liber $I I$.

Twórcy zbiorów pism, w momencie ich redakcji, korzystali $\mathrm{z}$ posiadanego przez siebie egzemplarza określonego wydania danego dzieła - często bez porozumienia z jego autorem. Niekiedy powtarzali tym samym błędy tego wydania. $Z$ tego punktu widzenia ciekawa jest analiza wznowień wspomnianej Oratio in funere...Sigismundi...regis M. Kromera, które ukazały się w ramach zbiorów J. Pistoriusa Polonicae historiae corpus z 1582 r. i Rerum Polonicarum tomi tres Aleksandra Gwagnina z $1584 \mathrm{r}$.

W zbiorze J. Pistoriusa ta część De origine et rebus gestis Polonorum libri $X X X$, która zawierała Oratio in funere..., składała siẹ z następujących elementów: tytułu, przedmowy do Zygmunta Augusta datowanej na $I Y$ Calend. Aug. 1548, epitafium J. Dantyss. 
niepodpisanego czterowiersza M. Kromera poświęconego Zygmuntowi Staremu i właściwego tekstu Oratio in funere... ${ }^{75}$ Wymienione elementy były charakterystyczne dla wydania Oratio in funere... w ramach edycji De origine... z 1555 r. W późniejszych wydaniach De origine... w części zawierającej mowę pogrzebową występują zmiany:

- w edycji z 1558 r. brak jest daty dziennej przedmowy do Zygmunta Augusta;

- $w$ edycji z 1568 r. zmienia się układ kompozycyjny tekstu. $\mathrm{Na}$ początku umieszczona jest przedmowa do Zygmunta Augusta, datowana tym razem na 15 Calend. Decembr. 1548. Dopiero po przedmowie następuje tytuł Oratio in funere..., epitafium Dantyszka, czterowiersz M. Kromera i właściwy tekst mowy.

Można stąd wnosić, że J. Pistorius tworząc swój zbiór posłużył się pierwszym, niepoprawionym - z 1555 r. - wydaniem De origine.... Nawiasem mówiąc $M$. Kromer miał o to pretensję do szwajcarskiego uczonego.

Charakterystyczne są problemy $z$ datacją wspominanej przedmowy do Zygmunta Augusta, dołączonej do Oratio in funere... Powinna ona według autora nosić datę 15 Calend. Decembr. 1548, a nie 9 Calend. Aug. jak wydrukował w swoim zbiorze J. Pistorius za wydaniem bazylejskim z 1555 r. Prawidłową datę 15 Calend. Decembr. 1548 M. Kromer zamieścił w wydaniu De origine... z 1568 r. i w zbiorze Polonia sive de origine et rebus gestis Polonorum libri XXX wydanym w $1589 \mathrm{r}^{76}$

Możliwości wpływu autora na twórców i wydawców zbiorów, którzy wykorzystywali jego dzieło, były bardzo ograniczone. Rynek wydawniczy rządził się często własnymi zasadami, niezależnymi od woli autora. W dwa lata po ukazaniu się zbioru J. Pistoriusa, w 1584 r. niemiecki wydawca S. Feyerabend podjął nową inicjatywę wydawnicza, publikując Rerum Polonicarum tomi tres A. Gwagnina. ${ }^{77}$ Nowy zbiór był w znacznym stopniu przedrukiem $z$ dzieła J. Pistoriusa uzupełnionym o pisma dotyczące najnowszej historii Rzeczypospolitej. O tym, że właśnie Polonicae historiae corpus stanowiło podstawę dla wydawców Rerum Polonicarum tomi tres, świadczy m.in. kolejna edycja Oratio in funere...Sigismundi...regis M. Kromera. Była w pełni zbieżna $\mathrm{z}$ wydaniem J. Pistoriusa, wraz $\mathrm{z}$ ową charakterystyczną datacja 9 Calend. Aug. 1548 przedmowy M. Kromera do Zygmunta Augusta. 
Niekiedy różnice - między polonikami opublikowanymi w polskich drukarniach, a ich niemieckimi odpowiednikami - były bardzo duze Wynikały zarówno $z$ innego opracowania redakcyjnego porównywanych edycji, jak również $z$ dużych zmian w treści dzieła. Jako przykład może służyć zbiór M. Kromera De falsa nostri temporis et vera Christi religione czyli Rozmowy Dworzanina z Mnichem. Dzieło powstało początkowo w wersji polskiej. Składało się zrazu z trzech części: O wierze $i$ nauce luterskiej. Rozmowa Dworzanina z Mnichem wydana w 1551 r., Czego się krześcijański człowiek dzierżé́ ma. Mnicha z Dworzaninem rozmowa wióra opublikowana w $1552 \mathrm{r}^{79}$ i O kościele Bozym albo Krystusowym. Mnicha z Dworzaninem rozmowa trzecia w 1553 r. $^{80}$ Wszystkie Rozmowy opublikowal Lazarz Andrysowicz. Wydrukował także kolejną edycję Rozmów, wydanych w jednym tomie w latach 1553/1554 razem z O nauce Kościola świętego. Rozmow'a Dworzanina z Mnichem czwarta $i$ ostateczna. Wymienione publitacje ukazały się bez podania nazwiska autora, który nie chciał podpisywać tekstu w języku polskim. Pod naciskiem środowiska autor zdecydował się na przygotowanie łacińskiej wersji dzieła, przeznaczonej dla bardziej wymagającego czytelnika. Dwie pierwsze części ukazały się w 1559 r. w Dillingen u Sebalda Mayera pt. De falsa nostri temporis et vera Christi religione. ${ }^{81}$ Zachodzi pytanie, $w$ jakim stopniu wydania polskie i łacińskie dwóch pierwszych Rozmów są zbieżne. Otóż wypada stwierdzić, że polskie teksty obu ksiagg stanowily swego rodzaju kompozycyjny szkielet, na którym autor zbudował szerszą pod względem objętości tekstu - łacińską wersję wymienionych utworów

Kolejna, trzecią część dzieła S. Mayer opublikował w 1561 r. pt. De vera et falsa religione colloquiorum liber tertius. Wszystkie Rozmon'y wydał w jednym tomie w 1568 r. Maternus Cholinus z Kolonii (Monachus, sive Colloquiorum de religione libri quatuor). Wydanie pełnej, poprawionej, łacińskiej wersji Rozmów zajęło więc M. Kromerowi kilkanaście lat. Jej ostateczny kształt daleko odbiegai od pierwszej, polskojęzycznej wersji dziela.

W pewnych przypadkach o tym, że polska edycja w znacznym stopniu różniła się od swojego niemieckiego odpowiednika, decydowaly uwarunkowania wydawnicze. Charakterystycznym przykładem problemów polskich autorów z krajowymi oficynami wydawniczymi są dzieje pierwszej edycji Confessio fidei catholicae Christiana St. Hozjusza

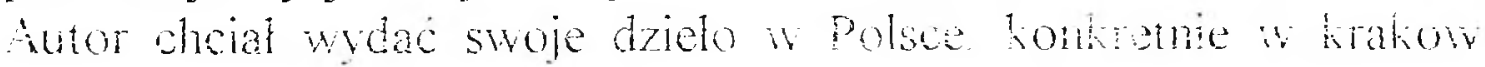


oficynie Macieja Scharffenberga. Drukarz otrzymał rękopis w 1552 r. i wykonał pierwodruk. St. Hozjusz ocenił go bardzo nieprzychylnie, ze względu na niedoskonały poziom edytorski i dużo błędów w tekście. W końcu jednak, po sporządzeniu erraty (zawierała 1200 błędów !), pierwszy tom dzieła ukazał się w 1553 r., tyle że bez podania nazwiska autora. ${ }^{83}$ Mimo tych doświadczeń St. Hozjusz pragnął aby również drugi tom Confessio..., przeznaczonego przecież dla polskiego czytelnika, ukazał się w Krakowie. Oficyna Scharffenbergów odmówiła jednak druku dzieła własnym nakładem, żądając, aby jego koszt pokrył episkopat polski. W tej sytuacji prymas Mikołaj Dzierzgowski zadecydował, że dzieło zostanie wydane za granica, w Wenecji bądź w Niemczech. Nakładem zajął się Jan Patruus mł. Wybrał drukarnię F. Behema w Moguncji. Confessio... w swoim pełnym wydaniu ukazało się tam w 1557 r. $^{84}$ Przedtem, według Karola Estreichera, ukazały się w Niemczech przedruki pierwszego tomu dzieła. ${ }^{85}$

\section{Polonika powstałe na obszarze niemieckojęzycznym.}

Największą grupę poloników stanowiły utwory powstałe w trakcie pobytu ich autorów w Niemczech. Część $z$ nich osiadła $w$ tym kraju na stałe. Na przykład na lata trzydzieste i czterdzieste XVI w. przypadaja pierwsze edycje dzieł Jodoka Willicha z Reszla, profesora uniwersytetu we Frankfurcie nad Odrą. Bogata twórczość naukowa J. Willicha ${ }^{86}$ była związana głównie $\mathrm{z}$ jego działalnością wykładowcy uniwersyteckiego, a ślady jego związków z Polską były mało znaczące. ${ }^{87} \mathrm{~W}$ jego przypadku można mówić tylko o formalnie polonikowym charakterze jego dzieł. Do tej grupy pisarzy należał także Johann Derschovius z Królewca. Był profesorem prawa uniwersytetu w Helmstadt, autorem wielu publikacji naukowych wydawanych $w$ tym mieście $w$ latach osiemdziesiatych XVI w.

Wielu autorów poloników z różnych względów przebywało czasowo w Niemczech. Wśród nich znalazł się m.in. J. Łaski mł. Kilka jego publikacji $z$ lat pięćdziesiątych XVI w. było związanych $\mathrm{z}$ reforma kościoła fryzyjskiego, jaką podjął sprawując urząd superintendenta na tym terenie.

Najliczniejsza grupa autorów składała się ze studentów uczelni niemieckich ${ }^{88}$ Utwory, które publikowali $w$ oficynach $\mathrm{z}$ obszaru niemieckojęzycznego, pochodziły zwykle z drugiej połowy XVI w. Ukazywały się $w$ takich miastach jak Strasburg, Bazylea, Wittenberga, 
Norymberga, Helmstadt czy Frankfurt nad Odra, a $\mathrm{z}$ katolickich w Würzburgu i Ingolstadt. Były wśród nich publikacje naukowe, ale także utwory o charakterze okolicznościowym (penegiryki, epitafia, pieśni weselne) oraz poezja religijna. Utwory te publikowano zwykle w pojedynczych edycjach.

4. Niemieckie wznowienia i niemieckojęzyczne mutacje poloników.

W przypadku wznowień poloników na obszarze niemieckojęzycznym regułą było to, że ich wydawcy korzystali z wcześniejszych, niemieckich jeśli takie istniały - edycji danego dzieła. Można to prześledzic na przykładzie kolejnych wydań De bello Moscovitico commentariorum libri sex Reinholda Heidensteina. Pierwsze wydanie ukazało się w 1584 r. w krakowskiej Oficynie Łazarzowej. ${ }^{89}$ Swoją książkę autor zadedykowal Zygmuntowi Batoremu, księciu Siedmiogrodu. Na podstawie owej dedykacji można określić kolejność i pochodzenie poszczególnych wydan dziejów wojny moskiewskiej. Istotny jest tutaj pewien szczegół. Otoż wspomniana dedykacja kończyła się $w$ wydaniu krakowskim fragmentem zawiera-jącym zwrot beneficij loco accepturus id sim. W nastẹpnej edycji, opublikowanej w Bazylei przez Konrada Waldkircha w 1588 r., ten sam fragment brzmiał następująco: beneficij loco id sim accepturus. Kolejna edycja De bello Moscovitico... ukazała się w zbiorze Polonica sive de origine... M. Kromera, wydanym w Kolonii w 1589 r. ${ }^{91}$ Redaktor zbioru Tomasz Płaza wykorzystał krakowskie wydanie De bello Moscovitico... z 1584 r. Świadczy o tym wspomniany fragment dedykacji oraz inicjały użyte w tekście De bello Moscovitico... Z kolei frankfurccy wydawcy zbioru Rerum Moscoviticarum auctores varii umum in corpus congesti z $1600 \mathrm{r}^{92}$ posłużyli się bazylejskim wydaniem, o czym lojainie poinformowali w spisie treści tomu.

Obok dzieła R. Heidensteina znalazła się w nim także De Moscorica Matthiae Michovia desumpta ex corpore historiae Polonicae Io. Pisiorii. edito Basileae $a b \mathrm{H}$. Petrici anno $15822^{93}$ Wydawcy frankfurckiego zbioru, zgodnie z zapowiedzią w spisie treści, dokładnie przedrukowali tekst dotyczący Moskwy z Tractatus de duabus Sarmatiis... Macieja z Miechowa. Źródłem przedruku był zbiór J. Pistoriusa. Rermm Moscoviticarum auctores varii...congesti zachowało nawet żywą paginę bazylejskiego druku, tj. Polonicarum rerum tomus I. 
Przy okazji warto sobie odpowiedzieć na pytanie, jakim wydaniem traktatu Macieja z Miechowa posłużył się J. Pistorius tworząc swój zbiór. $\mathrm{Na}$ podstawie analizy tekstu Tractatus de duabus Sarmatiis..., zamieszczonego w Polonicae historiae corpus, ${ }^{94}$ można stwierdzić, że J. Pistorius wykorzystał tutaj jedno $\mathrm{z}$ wydań dzieła Macieja z Miechowa, zamieszczonych w zbiorze Simona Grynaeusa Novus orbis regionum ac insularum. Wskazuja na to następujące cechy wydawnicze edycji S. Grynaeusa: zmienione nagłówki rozdziałów, komentarze na marginesach i brak podziału na części w obu księgach Tractatus de duabus Sarmatiis... ${ }^{95}$ Wyżej wymienione cechy nie występuja we wcześniejszych, łacińskojęzycznych wydaniach dzieła Macieja z Miechowa: krakowskich z $1517 \mathrm{r}^{96} \mathrm{i} 1521 \mathrm{r}^{97}$ oraz augsburskiego $\mathrm{z} 1518 \mathrm{r}^{98}$

Część poloników ukazywała się w niemieckojęzycznych tłumaczeniach $z$ edycji łacińskich. Często różniły się one stopniem zgodności tłumaczenia $\mathrm{z}$ łacińskim oryginałem. Dużą wiernością tłumaczenia w stosunku do tekstu oryginalnego wyróżniały się polonika o tematyce religijnej. Przy czym thumaczono nie tylko tekst właściwy dzieła, ale także dedykacje i przedmowy wydawnicze. Najwięcej thumaczeń z piśmiennictwa religijnego było dziełem niemieckiego teologa Johanna Baptisty Ficklera. Między innymi był autorem thumaczenia Censura orientalis Ecclesiae Jeremiasza z Konstantynopola, które wydał pt. Censur oder Urtheil der Orientalischen Kirchen. ${ }^{99}$

Do tradycyjnych zabiegów niemieckich thumaczy należało takie przeredagowanie tytułu przekładanego dzieła, aby stało się ono bardziej interesujące, frapujące dla czytelnika. Tak było w przypadku thumaczenia De origine et rebus gestis Polonorum libri $X X X \mathrm{M}$. Kromera. ${ }^{100}$ Przekładu dokonał Heinrich Pantaleon, twórca wielu dzieł historycznych poświęconych dziejom powszechnym, historii Kościoła, a także dziejom Niemiec $\mathrm{i}$ autor tłumaczeń $\mathrm{z}$ historycznego piśmiennictwa łacińskiego. ${ }^{101}$

Niemieckojęzyczny tytuł De origine et rebus gestis... brzmiał następująco: Mitnächtischer Völckeren Historien, Jn welcher viler Nationen, als nämmlich der Polen, deren Slauen, Pomeren, Reüssen, Moscoviten, Preüssen, Ungaren, Walachen, Schlesier, Littanweren, Wenden, Behemen, Tartaren, Tïrcken, Lyffländeren, Oesterreicheren, Podolier, Brandenburgeren, Irsprung, mancherley Gebreüche, nammhaffte Historien, Regiment unnd Ritterliche taathen, biss auff dise

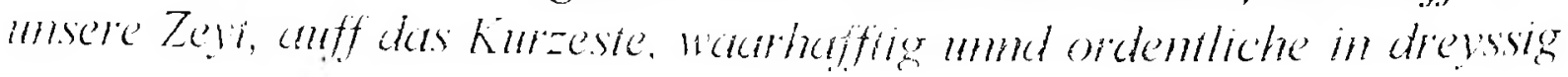


Bücheren begriffen. Erstlich durch den Hochgelerten Herren Martinum Chromer auss Poland zu Latein fleyssig beschriben: Jetz zumalen aber durch Heinrich Pantaleon...zu gutem gemeiner Teutscher nation, auff das treüwlichest verteütschet, gemehret. ${ }^{102}$ Ponieważ bazylejski uczony tłumaczył zapewne edycję oporinowską z 1558 r., warto dla porównania podać tytuł tego wydania: De origine et rebus gestis Polonorum libri $X X X$. Recogniti ab autore. Una cum funebri eiusdem autoris Oratione, Sigismundi Regis vitam compendiose complexa et aliquoties iam prius edita. Accessit modo iudicium Francisci Robortelli Utinensis de authore et libro. Jak wynika $\mathrm{z}$ powyższych cytatow, tytuł tłumaczenia H. Pantaleona w najmniejszym stopniu nie odpowiadał treści karty tytułowej łacińskiego oryginału. Dla thumacza nieistotne były w tym momencie informacje autora o zmianach, dokonanych w edycji $15.58 \mathrm{r}$., w stosunku do poprzedniego wydania De origine.... Ważniejsze było odpowiednie zareklamowanie dzieła niemieckiemu czytelnikowi poprzez ukazanie jego tematycznej rozległości i zasugerowanie popularnego, a nie naukowego, ujęcia opisywanych zdarzeń. Przy czym H. Pantaleon popełnił swego rodzaju nadużycie zapowiadając, że historia M. Kromera jest doprowadzona biss auff dise unsere Zeyt. Jak wiadomo De origine... kończyło się na 1506 r. Właściwy tekst, wraz z dedykacją do Zygmunta Augusta, H. Pantaleon przełożył bez żadnych zmian. Czasy Zygmunta 1 opisywały dołączane do kolejnych wydań historii M. Kromera: epitafium J. Dantyszka i Oratio in funere... Sigismundi...regis M. Kromera. Obu utworów H. Pantaleon nie przetłumaczył. Posłużył się natomiast mową M. Kromera oraz cytatami ze swoich dzieł i prac m.in. Paulo Giovio i Johanna Sleidana do stworzenia chronologicznie uporządkowanego, krótkiego spisu ważniejszych wydarzeń z dziejów Polski z lat 1506-1562 Thumacz pominął także list Francesco Robortello do M. Kromera, załączony do edycji De origine... z 1558 r. Dołączył natomiast mapę Europy, a także mapę Polski, Węgier, Rusi i Litwy, której tak brakowało w łacińskich wydaniach historii $\mathrm{M}$. Kromera. Należy jednak podkreslić, że główny tekst dzieła M. Kromera niemiecki tłumacz starał się przełożyc zgodnie $z$ brzmieniem oryginału. Nie zawsze podobne zamierzenia kończyły się sukcesem, tak jak w przypadku niemieckojęzycznegro przekładu De bello Moscovitico commentariorum libri sex R. Heidensteina. Jego autorem był Heinrich Rätel z Żagania, który wydal go pt. Warhafte, gründliche und eigentliche Beschreibung des Kriege's

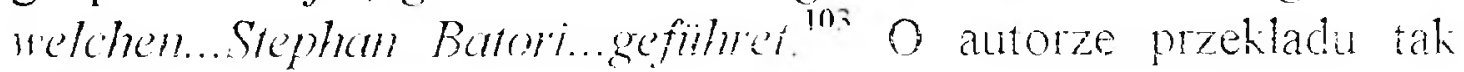


Stefan Zabłocki: choć starat się oddać stylistyczne wtaściwości oryginatu, trudno tu mówić o sukcesie. Zbyt często rozwadnia on zwięzłe zdania Heidensteina, upiększa je też retorycznymi ozdóbkami, przez co odbiera całości ów surowy, rzeczowy charakter. ${ }^{104}$ Thumaczenie dzieła R. Heidensteina było ukoronowaniem twórczości przekładowej H. Rätela, związanej z wojnami batoriańskimi. Największą liczbą wznowień w Niemczech cieszyło się jego thumaczenie pracy Paulusa Oderborna Joannis Basilidis Magni Moscoviae Ducis vita. ${ }^{105}$ Nosiło ono znamienny tytuł Wunderbare, erschreckliche, unerhörte Geschichte und warhaffte Historien.

Praca P. Oderborna miała $w$ wersji łacińskiej charakter w miarę obiektywnej biografii Iwana IV Groźnego. Thumacz wyeksponował jednak jej wątek sensacyjny, przekształcając ją w Wunderbare, erschreckliche, unerhörte Geschichte... Oczywiście tytuł w tym brzmieniu miał przede wszystkim zareklamować dzieło czytelnikowi. Podobny los spotkał dziełko A. Gwagnina wydane w 1581 r. pt. Gesta praecipua tyranniaque ingens Monarchae Moscoviae Joannis Basiliadis nuper perpetrata. ${ }^{106}$ Również w tym przypadku bezimienny thumacz uczynił $\mathrm{z}$ opracowania A. Gwagnina powieść przeznaczona dla masowego czytelnika, epatując go budzącymi grozę czynami Iwana IV Groźnego. Thumaczenie nosiło tytuł: Etliche Historien. ${ }^{107}$ Należy podkreślić, że podobny sposób ujmowania treści thumaczonych dzieł był zdeterminowany potrzebami popularnego rynku czytelniczego. Przy czym w przypadku publikacji poświęconych Iwanowi IV Groźnemu dużą rolę odegrała propagandowa intencja, ukształtowana w Niemczech w latach siedemdziesiątych i osiemdziesiątych XVI w. Jej istota było przedstawianie postaci cara $w$ jak najgorszym świetle. Podobna konwencja obowiązywała także w literaturze popularnej, poświęconej problematyce tureckiej. Jako przykład może posłużyć opis genezy i przebiegu wojny wołosko-tureckiej autorstwa Jana Łasickiego i Leonarda Goreckiego. Dziełko L. Goreckiego nosiło tytuł Descriptio belli Ivoniae Voievodae Valachiae a. 1574. Jego kontynuacje stanowiło opracowanie J. Łasickiego Historia de ingressu Polonorum in Valachiam cum Bogdano Voivoda et caede Turcarum. ${ }^{108}$

Bardzo szybko, bo już w tym samym roku, ukazało się thumaczenie obu ksiazzek autorstwa Nicolausa Hönigera. Opublikował je bazylejski drukarz Sebastian Henricpetri pt. Walachischen Kriegs oder Geschichten warhaffie Beschreibung... Ion der Polen Zug in die Walachey." 
Również w tym przypadku thumacz nie starał się oddać całości treści obu prac, stanowiących rzeczową - jak na owe czasy - relację historyczną. Skupił się natomiast na wątkach, które mogły przyciagnąć czytelnika literatury popularnej tj. opisie okrucieństw tureckich, podstępów i zdrad pogan. W przekładzie N. Hönigera relacje L. Goreckiego i J. Lasickiego stały się pseudohistorycznym romansem rycerskim poświęconym bohaterstwu Polaków, heroicznych obrońców chrześcijaństwa. ${ }^{110}$

5. Niemieckie przedruki $\mathrm{z}$ poloników opublikowanych $\mathrm{w}$ oficynach wydawniczych innych krajów europejskich.

W przypadku publikacji tego typu najczęściej można spotkać przedruki $z$ edycji włoskich. Pojawiały się już $w$ pierwszym dwudziestoleciu XVI w. ${ }^{111}$ We Włoszech ukazało się m.in. pierwsze wydanie mowy J. Dantyszka do papieża Klemensa VII i cesarza Karola V De nostrorum temporum calamitatibus silva. ${ }^{112}$ Antyluterańska wymowa tego utworu łączyła się z propagandą wizerunku Polski, jako ostoi katolicyzmu w Europie środkowo-wschodniej. Mowę J. Dantyszka wydano w 1530 r. w kilku europejskich centrach katolickich, w tym również w Kolonii.

$Z$ pierwszej połowy XVI w. pochodził jeszcze inny utwór, który zdobył ogólnoeuropejską sławę. Była nim mowa pogrzebowa Stanisława Orzechowskiego Funebris oratio habita...ad equites Polonos in funere Sigismundi Jagellonis. ${ }^{13}$ St. Orzechowski przesłał swój utwór włoskiemu humaniście Paolo Ramusio z Wenecji. Ten opatrzył Funebris oratio... przedmową a także epigramem pochwalnym i w takiej formie opublikował mowę w oficynie Tomasso Giunto w Wenecji w 1548 r. Później znalazła się w zbiorze Orationes clarorum hominum... ${ }^{114}$

Wśród poloników z obszaru niemieckojęzycznego, mających włoską proweniencję, dominowało piśmiennictwo naukowe. W większości przypadków były to dzieła $\mathrm{z}$ zakresu medycyny. $\mathrm{Z}$ druków wydanych w pierwszej połowie XVI w. można wymienić De urinis liber Claudiusa Galenusa publikowane w łacińskim tłumaczeniu Józefa Struśka. Pierwsze wydanie tego dzieła ukazało się w 1535 r. w Wenecji. Już w rok później Józef Zimmermann i Johann Bebel włączyli thumaczenie J. Struśka do zbiorowego wydania dziet C. Galenusa Opera. ${ }^{115}$

$\mathrm{Z}$ drugiej połowy XVI w. pochodzą natomiast wydania dzieł Joannesa Baptisty Montanusa. Ich redaktorem i wydawca był uczeni włosk 
uczonego Walenty Sierpiński z Lublina. Po powrocie do Polski w 1554 r. W. Sierpiński podjał się publikacji dzieł swojego mistrza, które wydawał w latach 1554-1557 w Wenecji. Zdobyły one dużą popularność w Europie, o czym świadczą ich wznowienia w oficynach włoskich, francuskich oraz niemieckich. Tak było w przypadku Consultationes de variorum morborum curationibus, które ukazały się w 1557 r. w bazylejskiej oficynie Michaela Insengrina. Redaktorem tej edycji był Hieronym Donzellini.

Z piśmiennictwa reprezentującego humanistyczne edytorstwo naukowe można wymienic m.in. wydanie dzieła Bazylego Wielkiego De moribus orationes XXIIII dokonane przez Stanisława Iłowskiego. Pierwsza edycja ukazała się w Wenecji w 1564 r. ${ }^{116}$ Po ponad trzydziestu latach, tj. w 1598 r. jego wznowienia dokonał drukarz i nakładca z Frankfurtu nad Menem Nicolaus Bassaeus. ${ }^{117}$ Dzieło miało służyć młodzieży studenckiej. Dzięki niemu mogłaby się zapoznać z zasadami kunsztu oratorskiego, studiować język i literaturę grecką, wreszcie poznać utwór wybitnego pisarza chrześcijańskiego. N. Bassaeus zdecydował się na podjęcie trudu reedycji mów Bazylego Wielkiego ponieważ, jak pisał w dedykacji do Teofila Rici, ${ }^{118}$ edycja poprzednia miała liczne błędy. Według wydawcy wynikały one $z$ tego, że włoska edycja była oparta na zdefektowanym egzemplarzu greckojęzycznego oryginału. Zaistniała więc konieczność dokonania poprawek w tekście tłumaczenia. Ponadto N. Bassaeus wprowadził kilka innych, ważnych zmian w stosunku do edycji weneckiej. Usunął zbędny podział na tomy. Ów podział wprowadził St. Iłowski, co stworzyło mu pretekst do zadedykowania poszczególnych tomów weneckiej publikacji biskupom polskiego kościoła katolickiego. ${ }^{119}$ Oczywiście N. Bassaeus pominał te dedykacje w swoim wydaniu. Zgodnie $\mathrm{z}$ kompozycją greckiego oryginału, który w odróżnieniu od weneckiej publikacji został dołączony do edycji frankfurckiej, wydawca zmienił także kolejność mów Bazylego Wielkiego. W świetle owych zmian wydawca miał prawo użyć na karcie tytułowej dzieła formuly munc primum in lucem edita, która w omawianym okresie była niekiedy tylko zabiegiem reklamowym. Frankfurcka edycja De moribus orationes XXIIII jest więc przykładem profesjonalizmu wydawców z obszaru niemieckojęzycznego. ${ }^{120}$

W drugiej połowie XVI w. znacznie rzadziej można spotkać niemieckie przedruki włoskich poloników o tematyce polityczno-prawnej.

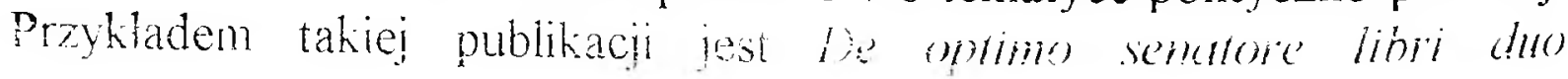


Wawrzyńca Goślickiego wydane po raz pierwszy w 1568 r. w Wenecj1. Jego wznowienie ukazało się w Bazylei. ${ }^{121}$ Niemieccy wydawcy korzystali nie tylko $\mathrm{z}$ włoskich edycji poloników. $\mathrm{Na}$ przykład oficyna wdowy po A. Wechelu, Claudiusa Marniusa i Joannesa Aubriusa z Frankfurtu nad Menem przedrukowała w 1600 r. z antwerpskiego wydania ${ }^{122}$ słownik do Poemata omnia Horacego autorstwa T. Tretera. ${ }^{123}$

6. Publikacje oficyn wydawniczych z obszaru niemieckojęzycznego jakio podstawa wznowień poloników w oficynach wydawniczych innych krajów europejskich.

Z przykładami publikacji tego typu można spotkać się zarówno w pierwszej jak i w drugiej połowie XVI w. Stanowiły one podstawę dla kilkunastu polskich edycji interesujących nas dziel. Należy jednak stwierdzić, że była to niewielka liczba w stosunku do całej produkcji poloników w oficynach obszaru niemieckojęzycznego. Warto zwrócić uwage na strasburskie wydania $\mathrm{i}$ ich polskie odpowiedniki Tractants sacerdotalis de sacramentis Mikołaja z Błonia. Strasburskie edycje tego dzieła, wydawane od końca XV w., były bardzo do siebie podobne $\mathrm{Na}$ przykład edycja J. Knobloucha z $1499 r^{124}$ jest prawie identyczna z wydaniami Tractatus sacerdotalis..., które ukazały się w tej oficynie w 1508 i 1512 r. ${ }^{125}$ Cechują się brakiem ozdobnych inicjałów i niezbyt czytelnym opracowaniem tablic. W porównaniu z nimi krakowskie wydanie Rudolfa Agricoli mt. ${ }^{126}$ prezentuje się znacznie korzystniej. Zarówno pod względem opracowania typograficznego - ładny, przejrzysty druk $z$ ozdobnymi inicjałami - jak i pod względem opracowania redakcyjnego, ponieważ tabula mają swój spis trésci z podaniem paginacji.

Niekiedy niemiecka publikacja dzieła stanowiła podstawę do jego polskiego wznowienia w zmienionej, rozszerzonej wersji. Przykładem jest kolońska edycja Parallela Ecclesiae Catholicae cum haereticoirtin Synagogis Andrzeja Patrycego Nideckiego z 1576 r. ${ }^{127} \mathrm{~W} 158$ i r w Oficynie Łazarzowej dzieło to ukazało się w zmienionej wersji pt to Ecclesia vera et falsa libri $r^{128}$ Podobnie rzecz sie miała $z$ thumaczenien Stanisława Sokołowskiego (enzury Jeremiasza z Konstantynopola. Thumacz podkreślał w dedykacji dla Grzegorza XIII, że przelożył pisno jeremiasza na podistavie sabo 
od greckiego uczonego Theolepta. ${ }^{129}$ Stąd wszystkie wydania - zarówno pierwsze, polskie z $1582 \mathrm{r}$. jak i niemieckie z lat 1582-1586 - miały drobne błędy w tekście tłumaczenia. Przygotowując wydanie swoich Opera, St. Sokołowski zamieścił w nich już poprawne tłumaczenie Censura orientalis Ecclesiae. ${ }^{130}$ Paradoksalnie - nowa edycja była oparta na oryginalnym tekście greckim, opublikowanym przez protestanckich teologów w Acta et scripta theologorum Wittenbergensium.... ${ }^{13}$

Niemieckie edycje poloników były podstawą do ich wznowień także w innych niż Rzeczypospolita krajach europejskich. Dotyczyło to przede wszystkim dzieł polskich teologów katolickich. ${ }^{132} \mathrm{Z}$ podobnymi publikacjami można spotkać się również w przypadku piśmiennictwa historycznego i polityczno-prawnego ${ }^{133}$ oraz naukowego. Jako przykład może posłużyć wznowienie Sphygmicae artis...libri $V$ J. Struśka, opublikowane $\mathrm{w}$ poprawionej wersji - nunc denuo diligentissimae emendati - w Wenecji w $1573 \mathrm{r}^{134}$ Publikacja ukazała się na podstawie wcześniejszej, bazylejskiej edycji dzieła z $1555 \mathrm{r}^{135}$

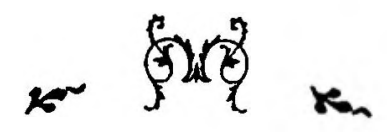

Przypisy:

1 Niniejsze opracowanie jest wyborem fragmentów $\mathrm{z}$ pracy doktorskiej napisanej pod kierunkiem prof. dr hab. Barbary Bieńkowskiej. Maszynopis w zbiorach biblioteki INNiSB UW, sygn. Dr 41.

${ }^{2}$ B. Otwinowska, Renesans. W: Stownik literatury staropolskiej (Średniowiecze-renesansbarok) pod red. T. Michałowskiej przy udziale B. Otwinowskiej, E. Sarnowskiej-Temeriusz, Wroclaw 1990, s. 699-700.

${ }^{3}$ Por. K. Piekarski, Ksiqżka w Polsce. IV i XVT wieku. W: Kultura staropolska. Kraków 1932, s. 352-384; W. Voisé, Prace polskich uczonvch w oficynach bazylejskich epoki renesansu, Roczniki Biblioteczne 1960 r. z 1/2 s. 25-41; T. Ulewicz, W'śód impresorów krakowskich doby renesansu, Kraków 1977; M. Juda, Przywileje drukarskie w Polsce, Lublin 1992.

${ }^{4}$ Por. H. Barycz, Dzieje nauki w Polsce epoki odrodzenia, Warszawa 1957.

${ }^{5}$ Por. St. Kot, Polska ztotego wieku a Furopa. Studia i szkice. Warszawa 1987

"Por. T. Bieńkowski, Proza polkko-lacińska 1450-1750. Kierunki rozwoju i osiqgnięcia W: Problemy literatury staropolskiej. Seria II. Wroclaw 1973. s. 103-163: S. Zablocki. 
Od prerenesansu do oświecenia, Warszawa 1976; Literatura staropolska w kontekście europejskim, Wroclaw 1977; J. Pelc, Europejskość i polskość literatury naszego renesan.u. Warszawa 1984.

${ }^{7}$ Por. J. Tazbir, Polskie przedmurze chrześcijańskiej Europy. Mity a rzeczywistość historyczna, Warszawa 1987; Polska w Europie XT7 stulecia, Warszawa 1973; Polska w epoce odrodzenia. Państwo, spoteczeństwo, kultura. Pod redakcja A. Wyczańskiego, Warsıana 1986.

${ }^{8}$ W: Z dziejów polsíliej ksiazki w okresie renesansu, Wroclaw 1975.

${ }^{9}$ Tamże, s. 125.

${ }^{10}$ Por. J. Pirożyński, Z dziejów obiegu informacji w Europie ITI wieku. Nowiny z Polski w kolekcji Jana Jakuba Wicka w Zurychu z lat 1560-1587. Kraków 1995, a lakic R. F. Arnold, Geschichte der deutschen Polenliteratur von den Anfängen bis 1800 . Band 1., Halle 1900; H. Barycz, Z epoki renesansu, reformacji i baroku. Pradv - idee ludzie - ksiqżki, Warszawa 1971; M. Fischbach-Pospelova, Polnische Literatur in Deutschland, Meisenheim am Glan 1960; L. Kurtzmann. Die polnische Literatur in Deutschland bibliographisch zusammengestellt, Poznan 1881; M. Szyrocki, Polnische Schriftsteller der Renaissance und Deutschland, Aufbau $1955 \mathrm{Nr} 11$ H. 4 S. 301-307: Tenże, $Z$ dziejów powiazań literackich polsko-niemieckich w okresie od średniowiecza do baroku. W: Literatura staropolska.., s. 201-208.

${ }^{11}$ Por. J. Berger-Mayerowa. Nie znane Estreicherowi polonica i silesiaca w starodrukach Biblioteki Ślaskiej. Z.1-2, Katowice 1961; Bibliografia literatury polskiej "Nowv Korhu". Red. K. Budzyk. T. 2-3, Warszawa 1964-65; K. Estreicher, Bibliografia Polska. C\%3 T.13-34, Kraków 1891-1951; M. Bohonos. Katalog starych druków Biblioteki Zakladu Narodowego im. Ossolinskich. Polonica wiekin I77. Wroclaw 1965; Katalog polonikim XTI wieku Biblioteki Jagiellonskiej. T.1-3. Oprac. M. Malicki i E. Zwinogrod M. Goluszka i inni, Warszawa-Kraków 1992-1994: Katalog starvch druków Biblioteki Publicznej m. st. Warszawy. Część 2. Polonica XTI wieku. Oprac. A. Kawecka-Gryczowa. Warszawa 1957; L. Kurtzmann, Die polnische Literatur in Deutschland...; J. Ożóg. Katalog poloników ATT w. Biblioteki Uniwersyteckiej we Hrockawiu. Tom I. Katalog. Częic I. A-K., Wroclaw 1992; K. Piotrowicz. Polonika w Viemczech. Kraków 1934: Polonica . II do XIII wieku nie znane bibliografii Estreichera ze zbiorów Biblioteki (idanskiej. Z. I-3. Gdańsk 1980; Verzeichnis der im deutschen Sprachbereich erschienenen Druktis des 16. Jahrhunderts, Stuttgart 1983-1994.

${ }^{12}$ W większości opracowań dotyczących historii książki niemnicckicj - z wyjątkami tainimi jak np. Handbuch der Bibliothekswissenschaft - cpokę odrodzenia traktuje się jako okres zamknięty końcem wieku. Zob. K. Malcczyńska, Zatozenia metodologiczne praviszlej historii ksiqżki, bibliotek i czvtelnictu'a na Slqusku, Roczniki Biblioteczne 1988 z. 1 s. 83.

${ }^{13}$ Można w tym kontekście wymienić takich pisarцy jak np. Wawrzyniec Korwin. 1ysszlof Hegendorfin, Jerzy Joachim Retyk. czy A. Gwagnin. Z drugiej strony przedmioten analizy były tylko te wiedeńskie druki $\mathrm{H}$. Wietora i Rafala Hoffhaltera-Skrzetuskiego, kiore należaty do poloników $\mathrm{z}$ autorskiego punktu widzenia.

${ }^{11}$ H. Neß, Der Buchdrucker - Bürger des Handwerks. Berufserfahrung und Berufse'si'hung, Wetzlar 1992, S. 169, 146; F. Funke, Buchkunde. Ein Uherblick über die Ceschichte

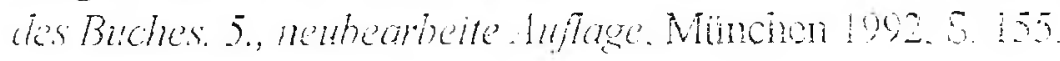


${ }^{15}$ R. Wittmann, Geschichte des deutschen Buchhandels. Ein Überblick, München 1991, s. 68; Verzeichnis der in deutschen..., S. XIV; W polskiej literaturze przedmiotu szacowano dotychczas calą produkcję europejską na ok. 150.000 tytulów (zob. np. B. Bieńkowska, H. Chamerska. Tysiac lat ksiażki $i$ bibliotek $w$ Polsce, Wroclaw 1992, s. 40; P. Rybicki, Odrodzenie. W: Historia nauki polskiej. T.1, Warszawa 1970, s. 220). Jeśli chodzi o obszar niemieckojęzyczny to wedhug A. Wyczańskiego liczba opublikowanych tam tytułów wynosila ok. 46.000 pozycji (zob. W: Polska $w$ Europie XII stulecia..., s. 201). Zbliżone do niemieckich ocen dane podaje najnowsze opracowanie J. Pirożyńskiego. Wedhug nich niemiecka produkcja wydawnicza wynosila, bez druków ulotnych, ok. 160.000-190.000 tytułów (zob. J. Pirożyński, $Z$ dziejów obiegu informacji w Europie XVI wieku..., s. 37).

${ }^{16}$ R. Wittmann, Geschichte des deutschen Buchhandels..., S. 68.

${ }^{17}$ K. Piekarski, Ksiażka w Polsce XV i XIT wieku..., s. 377.

18 A. Kawecka-Gryczowa, Rola drukarstwa polskiego $w$ dobie odrodzenia. W: Odrodzenie w Polsce 1956 T.4 s. 499.

${ }^{19}$ Tamże, s. 498; W: Z dziejów polskiej ksiqżki..., s. 116 A. Kawecka-Gryczowa podaje inne liczby. Wedhug niej w Polsce ukazalo się ok. 4.200 tytulów (ok. 3450 w Krakowie i ok. $750 \mathrm{w}$ drukarniach prowincjonalnych).

${ }^{20}$ A. Kawecka-Gryczowa obliczala, że w pierwszej połowie XVI w. ukazalo się za granica 140, a w drugiej 584 poloników (A. Kawecka-Gryczowa, Rola drukarstwa polskiego..., s. 498).

${ }^{21}$ Warszawa 1967.

${ }^{22}$ M. Czarnowska, Ilościowy rozwój..., s. 20. Podobną wielkość repertuaru wydawniczego ok. 8.000 tytutów [w znacznym zaniżeniu] podają B. Bieńkowska, H. Chamerska, Op. cit, s. 38. ${ }^{23}$ Tamże, s. 38.

${ }^{24}$ Por. B. Bieńkowska, Staropolski świat ksiażek, Wroclaw 1970; L. Hajdukiewicz, Biblioteka Macieja z Miechowa, Wroclaw 1960; Tenże, Ksiegozbiór i zainteresowania biblioflskie Piotra Tomickiego na tle jego dziatalności kulturalnej. Wroclaw 1961: K. Hartleb, Biblioteka Zygmunta Augusta. Lwów 1928; L. Jarzębowski. Biblioteka Mikolaja Kopernika, Toruń 1971; W. Jabłońska. Inwentarze $i$ katalogi biblioteczne $w$ zbiorach rękopiśmiennych Biblioteki Zaktadu im. Ossolinskich, Ze Skarbca Kultury 1969, s. 111-153; B. Kosmanowa, Ksiazkka i jej czytelnicy w dawnej Polsce, Warszawa 1981; A. Lewicka-Kamińska, Renesansowy księgozbiór Mikolaja Czepla w Bibliotece Jagiellońskiej, Wroclaw 1966; J. Puchalski. Literatura polityczna w siedemmastowiecznvch ksiegozbiorach szlachty koronnej w świetle produkcji w'vdawniczej krajowvch oficyn drukarskich z lat 1501-1732, Z Badań nad Polskimi Księgozbiorami Historvcznvmi 1993 T.15: Zbiory rozproszone, s. 43-83; J. Skoczek. Krakowskie inwentarze bibliotek w' epoce humanizmi renesansovego, Sprawozdania z Cynności i Posiedzen PAN w Krakowie 1950 nr 9; Tenże, Lwowskie inwentarze biblioteczne $w$ epoce renesansu. Lwów 1939; T. Strzembosz. Jan Strzembosz (1545-1606). Jego rękopis i księgozbiór, Roczniki Biblioteczne 1959, s. 401-423: W. Szelinska, Biblioteki profesorów Liniwersvtetu Krakonskiego w. XV i poczatkach XV7 w., Wroclaw $1966 \mathrm{i}$ inni.

${ }^{25}$ Licząc bez wznowień bylo to 676 tytulów. autorsiwa 251 pisarạ

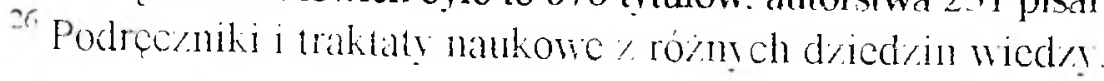


${ }^{27}$ Druki liturgiczne, kaznodziejskie, traktaty i polemiki teologiczne.

${ }^{28}$ Rozprawy z zakresu teorii historii, calościowe ujęcia dziejów Rzeczypospolitej. historia konfliktów zbrojnych, historia regionalna, biografistyka, hagiografia i zarysy geograficzno-historyczne. Traktaty i publicystyka polityczno-prawna. literatura propagandowa oraz relacje i druki okolicznościowe. Traktaty i rozprawy poświęcone teorii i praktyce prawniczej.

${ }^{29}$ Ok. 160 tytułów. Ok. 10 pozycji ukazalo się w pierwszej polowie XVI w., a ok. 150 w drugiej.

${ }^{30} \mathrm{~Np}$. co najmniej 10 publikacji J. Łaskiego ml. w języku holenderskim i jedną we francuskim (Forma ac ratio tota ecclesiastici ministerii in peregrinorum, potissimum vero Germanorum ecclesia, instituta Londini in Anglia, per...regem Edvardum cius nominis Sextum anno post Christum natum 1550, wydana we francuskim thumacreniu Gilelmusa Ctematiusa w 1559 r.) wydał G. Ctematius z Emden (1554-1556).

${ }^{31}$ Grecki tekst dziela lączono zwykle z jego lacińskim tlumaczeniem.

${ }^{32}$ Wydawano je m.in. w Wittenberdze, Magdeburgu i Kolonii.

${ }^{33} \mathrm{~Np}$. węgierskie tłumaczenie kalendarza na rok 1562 Tomasza Piotrkowczyka, które opracowal i wydal, w Wiedniu w oficynie R. Hoffhaltera-Skrzetuskiego, Péter Borncmisza.

${ }^{34}$ Nie licząc wznowień bylo to 868 tytulów.

${ }^{35} \mathrm{~W}$. Voisé, Poczatki nowożytnych nauk spolecznych. (Epoka renesansu, jej narodzim. i schytek), Warszawa 1962, s. 224-225.

36 Trudno uznać większość dysertacji za autorskie publikacje. Można mówić najwyżcj o wspólautorstwie. Dlatego też, aby nie zafalszowywać obrazu polskiej aktywności na niemieckim rynku wydawniczym, dysertacje potraktowano jako publikacje profesorów niemieckich uczelni.

${ }^{37}$ Byly to m.in. polskie części kolejnych edycji tzw. slownika Kalepina (od autora Ambrogio Calepino, którego dzielo wydawano w poszerzanych wersjach co kilka lat poczawszy od 1502 r.); teksty zawarte w drukach liturgicznych czy np. polskie thumaczenie Nowego Testamentu, opublikowane w 1599/1600 r. przez Eliasa Huttera z Norymbergi w ramach wielojęzycznej edycji Testamentum Novum.

${ }^{38}$ Nie liczac wznowień było to 468 tytulów.

${ }^{39}$ Co najmniej 457 pozycji, przy czym 79 pochodziło z pierwszej polowy XVI a $279 \mathrm{z}$ drugiej.

${ }^{40}$ Bez wznowień bylo to 368 tytulów, autorstwa 224 pisarzy.

${ }^{41} \mathrm{~Np}$. De origine et rebus gestis Polonorum libri $\mathrm{Lll}$ opublikowanc w $1555 \mathrm{r}$.

42 M.in. podręcznik dla kaznodzici Walentego Wróbla Opusculum Quadragesimale opublikowany w 1537 r. przez Mclchiora Lottcra z. Lipska i inne.

${ }^{13}$ Można wymienić dzielo Jakuba Górskicgo Commentariorum artis dialecticae libr decem opublikowane w 1563 r. Lipsku. czy Benedykta Herbesta Periodicae responsionis libri $V$ - traktat opublikowany w 1566 r. także w Lipsku.

${ }^{44}$ Część poloników ukazywala się w Niemczech na podstawie ich rękopiśmienmych odpisów. Dotyczylo to glównie dziel pisarzy, tworzących w stuleciach poprzedzającrich epoke XVI w. Tak byo min. w przypadku edycji dziela F. Kallimacha Historia de rege

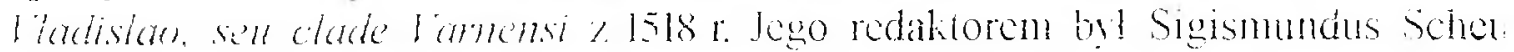


Wydanie miało wiele błędów, zwłaszcza w nazwach geograficznych (właściwa pisownia nazw była jednym $\mathrm{z}$ największych problemów niemieckich redaktorów, tlumaczy i wydawców poloników). S. Scheufler zdawał sobie sprawę z braków tej edycji. Thumaczył je - w liście do Aegidiusa Rema - poziomem odpisu dziela, na podstawie którego przygotowywał jego edycję. Podkreślal, że odpis został sporządzony przez nieudolnego kopistę. S. Scheufler postulowal w liście konieczność przeprowadzenia kwerendy w wegierskich i polskich bibliotekach. Jej celem miałoby być wyszukanie i opublikowanie kolejnych prac F. Kallimacha - m.in. mowy do Innocentego VIII bowiem: Quod aut haec historia usq.; in presens edita non est, in causa fuisse existimo quod inibi certamina et domi et militie inter utriusq.; Regni Proceres habita explicantur ...tametsi ea usus est modestia Callimachus ut neminem mea quidem coniectura, inde irritari posse credam. Zob. E XIV, s. 21.

${ }^{45}$ Próby kontroli nad publikacją dziel wynikaly z niebezpieczeństwa wydawania książek bez zgody autorów. Podobny przypadek opisywala przedmowa M. Kromera do Polonia sive de situ... z 1577 r. Dzielo ukazalo się w Kolonii w oficynie M. Cholinusa. W przedmowie M. Kromer podkreślal, że edycję z 1577 r. należy traktować jako pierwszą. Twierdzil, że wydanie poprzednie z $1575 \mathrm{r}$. (opublikowane przy Wandalia Alberta Krantza) jest wydaniem nielegalnym, ponicważ ukazalo się bez jego wiedzy. Co gorsza znalazlo się tam dużo błędów i przeinaczeń. Wynikaly z tego, że M. Kromer napisał swoje dzielo naprędce i niedoktadnie. Podkreślal, że różne zatrudnienia kazały mu ten plód niedoskonaly, niedonoszony zupetnie zaniedbać (zob. E XX, s. 281). Wrócil do Polonii pod wplywem Stanislawa Karnkowskiego, który pragnal ofiarować dzielo Henrykowi Walezemu. Autor podjąl więc pracę nad korektą Polonii. St. Karnkowski wręczył królowi poprawiony rękopis, witając go na granicy Polski. Kopię rękopisu ktoś sobie przywlaszczyl i przekazal A. Wechelowi. Frankfurcki drukarz opublikowal ją, nie podając nazwiska autora. Powyższe okoliczności zmusity M. Kromera do poprawnego wydania dziela w oficynie M. Cholinusa.: BN sygn.XVI.0.652.

${ }^{46}$ Warto w tym miejscu wspomnieć o redakcyjnych pracach T. Plazy. Przygotowywal m.in. nowe wydanie De origine et rebus gestis Polonorum..., które ukazalo się ostatecznie w Kolonii w 1586 r. pt. Polonia, sive de origine... T. Plaza przesylal stopniowo wydawcy zbioru Arnoldowi Myliusowi jego poszczególne fragmenty. Podobny sposób dostarczania tekstów wydawcy rodzil wiele problemów. Swiadczy o tyın kolońska edycja zbioru De falsa nostri temporis et vera Christi religione M. Kromera. W 1568 r. zostala wydana pod nowym tytulem: Monachus sive colloquiorum de religione libri tres... Colloquiorum de religione liber quartus qui est de doctrina Ecclesiae. $W$ przedmowie do tego wydania drukarz $M$. Cholinus pisal, że chociaż na karcic tytulowej zapowiada publikacje wszystkich. czterech ksiag dzieła, to jednak w rzeczywistości wydaje tylko trzy księgi. Stało się tak dlatego, że M. Kromer nie przesłal drukarzowi obiecanej, czwartej księgi Colloquiorum de religione liber quartus qui est de doctrina Ecclesiae. Przepraszajac czytelnika za to uchybienic, M. Cholinus zapowiadal wydanie i tej księgi. I rzeczywiście, w tym samym $1568 \mathrm{r}$. koloński drukarz otrzymal czwartą ksiegę zbioru. Natychmiast więc wznowil cale dzielo (19onachus, sive Colloquiorum de religione libri quatuor) już zo zmienioną karta tytulowa. Tym razem. 
zgodnie $\mathrm{z}$ zapowiedzia na karcie tytułowej druku, byla to pelna edycja. BN sygn.XVI.0.670.

${ }^{47}$ BN sygn. XVI.Qu.315.

${ }^{48}$ BN sygn. XVI.Qu. 16177.

${ }^{49}$ BN sygn. XVI.Qu.314.

${ }^{50}$ BN sygn. XVI.Qu.315.

${ }^{51} \mathrm{~Np}$. w egzemplarzu BN sygn. XVI.Qu.246.

${ }^{52}$ Dzieło ukazało się po raz pierwszy w Krakowie w 1506 r.

${ }^{53}$ BN sygn. XVI.Qu.257.

${ }^{54}$ BN sygn. XVI.Qu. 156.

${ }^{55}$ BN sygn. XVI.Qu.161.

${ }^{56}$ M.in. dzieło Jana z Glogowa (Minoris Donati interpretatio) - pierwsze wydanie polskie w Krakowie u J. Hallera w 1503 r., a niemieckie w 1505 r. w Lipsku u Wolfganga Stöckela.

${ }^{57} \mathrm{~Np}$. tłumaczenie S. Sokołowskiego listu Jeremiasza z Konstantynopola do teologów protestanckich Censura orientalis Ecclesiae opublikowane w Krakowie w Oficynie Łazarzowej w 1582 r. i przedrukowane w tym samym roku w Dillingen w oficynie Johanna Mayera.

${ }^{58}$ BUW sygn. Sd.612.310.

${ }^{59}$ W Krakowie w oficynie Mateusza Siebeneichera w 1563 r.: BUW sygn.28.3.4.32.

${ }^{60}$ W Krakowie u wdowy po H. Wietorze: BN sygn.XVI.0.46.

${ }^{61}$ Kolejne przedruki mowy pogrzebowej M. Kromera ukazały się w bazylejskich wydaniach De origine et rebus gestis Polonorum libri XXX; w Polonicae historiae corpus J. Pistoriusa (Bazylea 1582 r.); w Rerum Polonicarum tomi tres A. Gwagnina (Frankfurt nad Menem 1584 r.); w Polonia, sive de origine... M. Kromera (Kolonia 1589 r.) oraz w Orationes historicae Melchiora Juniusa (Strasburg 1598 r.).

${ }^{62}$ BN sygn. XVI.302.

${ }^{63}$ Wydane po raz pierwszy u wdowy Unglerowej w 1548 r. BN sygn. XVI.0.126.

${ }^{64}$ Wraz z czterowierszem M. Kromera poświęconym Zygmuntowi Staremu opublikowanym po raz pierwszy przez P. Giovio w Elogia virorum bellica virtute illustritum (Florencja 1548 r.).

${ }^{65}$ Bazylea 1555 r.: BN sygn. XVI.F.122, Bazylea 1558 r.: BN sygn. XVIF.138 i Bazylea 1568 r.: BN sygn. XVI.F.52 oraz Kolonia w 1589 r. -w ramach Polonii -BN sygn. XVIF.185. 66 Świadczy o tym przedmowa A. Bakschaya do O. Łaskiego. Autor podkreślil. że wydaje swoje dzieło w imieniu samego O. Łaskiego.

${ }^{67}$ J. Sambucus pozostawal w ścisłym kontakcie - m.in. za pośrednictwem A. Dudyc $/ a$. osiadlego w Polsce w latach 1567-1576 - z polskimi humanistami ze środowiska kalwińskiego. Do jego znajomych należeli m.in. J. Łasicki i K. Trecy. Interesowal się Polską z racji swoich prac nad dziejami Węgier. Posiadał w swoich zbiorach polonika: dzieła L. Goreckiego, Jana Herburta, St. Hozjusza, St. Ilowskiego. Mikolaja Kopernika, M. Kromera, J. Łasickiego, Macieja z Miechowa, Andrzeja Frycza Modrzewskiego, A. Patrycego Nideckiego, St. Orzechowskiego i Jana Zamoyskicgo (zob. J. Ślaski, Literatura staropolska a literatura starowęgierska. W: Literatura staropolska... s. 187). Polskic sprany byly jednak na marginesic zainteresondi 
J. Sambucusa. Przede wszystkim był humanistą zamiłowanym w antyku. Największą slawę w Europie przyniosła mu rękopiśmienna biblioteka grecka. Korzystał z niej m.in. Christoph Plantin. Pisal o tym niemiecki polihistor Michael Neander w Orbis terrae divisio, dziele opublikowanym w lipskiej oficynie Georga Deffnera w $1586 \mathrm{r}$. (zob. BN sygn. XVI.0.6124 na k. F 6 verso).

${ }^{68}$ Obok mowy O. Laskiego, przedmowy A. Bakschaya i jego Chronologia de rebus Hungaricis, wiersza A. Trzecieskiego ml., znalazły się tam także epigramy dworzan O. Łaskiego: Jana ze Świdnicy i A. Schroetera.

${ }^{69}$ Chodzi o bazylejskie wydanie Rerum Ungaricarum... z 1568 r.:BUW sygn Sd.612.211.

${ }^{70}$ BUW sygn. Sd.612.195.

${ }^{71}$ T.2, s. 1-259: BN sygn. XVI.F.159.

${ }^{72}$ BN sygn. XVI.F.803.

${ }^{73}$ W zbiorze J. Pistoriusa na s. 199, a w edycji krakowskiej na s. 290.

${ }^{74}$ Chodzi o rozdział $11 \mathrm{w}$ księdze 3 wydania krakowskiego, będący wlaściwie rozdziałem 12-tym, tak jak to oznaczył J. Pistorius na s. 93 swojej edycji.

${ }^{75} \mathrm{~W}$ samoistnych wydawniczo edycjach De origine... zamieszczony byl także portret Zygmunta Starego, pominięty w zbiorze J. Pistoriusa.

${ }^{76}$ BN sygn. XVI.F. 185.

${ }^{77}$ BN sygn. XVI.0.613.

${ }^{78}$ BN sygn. XVI.0.58.

${ }^{79}$ BN sygn. XVI.0.59.

${ }^{80}$ BN sygn. XVI.0.60.

${ }^{81}$ BN sygn. XVI.Qu.913.

${ }^{82} \mathrm{O}$ historii wydania Confessio... m.in. Andreas Eichhorn, Der ermländische Bischof und Cardinal Stanislaus Hosius. Vorzüglich nach seinem kirchlichen und literarischen Werken geschildert, Mainz 1854-85. 2 Bd.

${ }^{83}$ W Krakowie w oficynie dziedziców M. Scharffenberga.

${ }^{84}$ BN sygn. XVI.Qu 914 adl.

${ }^{85}$ W 1554 r. w Dillingen i w 1555 r. w Moguncji - zob. E XVIII, 281.

${ }^{86}$ Reprezentująca takie dziedziny wiedzy jak gramatyka języka lacińskiego, naukowe edytorstwo dziel autorów starożytnych i ojców Kościola, medycyna, retoryka, logika i teologia, np. Observationes in libellum Lactantii Firmiani qui de opificio Dei inscribuntur, wydane w 1542 r. w strasburskiej oficynie Krafta Müllera.

${ }^{87}$ Willich (Wilcke. Wild) Jodok. Zob. Historia nauki polskiej. T. 6.... s. 743-744.

${ }^{88} \mathrm{~W}$ latach dwudziestych XVI w. moda na studia zagraniczne obejmowala początkowo tylko synów mieszczan obcego pochodzenia z miast pruskich. Krakowa i Poznania. Od $1530 \mathrm{r}$. studia na niemieckich uniwersytetach podejmuje równicż rdzcnnie polska młodzież. Świadczą o tym m.in. publikacje Stanisława Chróścicjewskiego. w latach 1534-1538 studenta wydzialu filozoficznego Uniwersytetu Lipskiego (np. De encomiis poetarum elegia, wydana w Lipsku w 1538 r.). Okres pierwszych polskich peregrynacji zostal nieco zahamowany przez edykty Zygmunta Starego z. 1535 r. i 154 ) r.. zakazujące podróży do europejskich miast różnowierczych. Nie byly ściśle przestrzegane, zwłaszcza edykt z 1540 r. (zob. Historia 1 kad:mii.. T1 s 24E-240). Studia zagranicznc

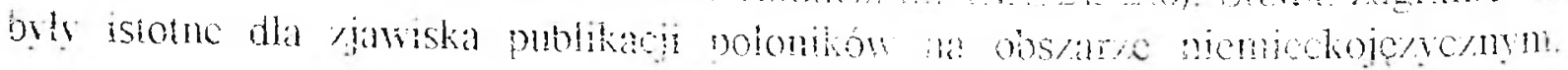


Ta forma kształcenia, oprócz różnorodnych kontaktów, dawala znajomość humanistycznej laciny, a więc i dorobku kulturalnego intelektualnej Europy. Pozwalala tym samym na dostosowanie swojej twórczości do wymagań europejskiego rynku ksiałki. Bez takiego wykształcenia komunikacja intelektualna w skali międzynarodowej bỵlaby niemożliwa, a recepcja piśmiennictwa lacińskiego ograniczona. O znaczeniu percgrynacji może świadczyć fakt, że większość wybitniejszych pisarzy, których dziela wydawano na obszarze niemieckojęzycznym $w$ szczytowym okresie natężenia tego zjawiska, tzn. w drugiej polowie XVI w., miala za sobą studia tego typu.

${ }^{89}$ BUW sygn. 28.20.2.459.

${ }^{90}$ BN sygn. XVI.Qu. 843.

${ }^{91}$ BN sygn. XVI.F. 185 , s. 733-837.

92 Zbiór opublikowała frankfurcka spólka dziedziców A. Wechela, Cl. Marniusa i J. Aubriusa: BUW sygn. Sd.612, s. 326-436.

${ }^{93}$ BUW sygn. Sd.612, s. 206-209.

${ }^{94}$ BN sygn. XVI.F. 159, s. 121-150.

${ }^{95}$ Bazylea u Joannesa Herwagena w 1532 r.: BUW sygn. Sd. 612.11. s. 482-531 bąd' wydanie tej samej oficyny z 1537 r.: BUW sygn.Sd.612.143, s. 485-531.

${ }^{96}$ BUW sygn. 28.2.3.43.

${ }^{97}$ BUW sygn.28.2.3.32. pt. Descriptio Sarmatiarum Asianae et Europianae.

${ }^{98}$ BN sygn. XVI.Qu. 969.

${ }^{99}$ Dzieło ukazalo się w 1583 i w 1585 r. w ingolstadzkiej oficynie Davida Sartoriusa. Tlumaczenie powstało na zlecenie Wilhelma V Pobożnego. Zob. E XVIII, s. 187 Tak jak J. B. Fickler podkreślał w tytule dzieła, jest ono wiernym przekładem nie tỵlko tekstu Jeremiasza, ale i towarzyszacych mu adnotacji St. Sokolowskiego. Thumacrcnic obejmowalo także dedykację St. Sokolowskiego dla Grzegorza XIII, mająca w durcj mierze charakter autorskiej przedmowy wydawniczej.

${ }^{100}$ Wydanego w 1562 r. w Bazylei.

${ }^{101}$ M.in. tlumaczyl dziela P. Giovio i Sigismunda Herbersteina.

${ }^{102}$ BN sygn. XVI.F.235.

${ }^{103}$ Zgorzelec w 1590 r. zob. E XVIII. s. 80.

${ }^{104}$ St. Zablocki, Od prerenesansu..., s. 132.

105 Pierwszy raz wersję niemiecką H. Rätel wydał w 1586 r. w Zgorzelcu. Zob. E XXIII, s. 252.

${ }^{106}$ Ukazało się zapewne w oficynie Bernarda D'Albina ze Spiry niemieckiego wydawcy Sarmatiae Europeae descriptio.

${ }^{107}$ W oficynie B. D'Albina ze Spiry w 1582 r. E XVII, s. 480.

${ }_{108}$ Obie relacje opublikowal w jednym tomie A. Wechel we Frankfurcie nad Menem w $1578 \mathrm{r}$.

${ }^{1119}$ E XVII. s. 249.

11ii St. Zablocki. Od prerenesansu.... s. 132-133.

111 Należało do nich m.in. bazylejskic wydanie Epistola...ad Leonem I' de victoriu contra...schismaticos Moscovios Zygmunta I Starego. Picrwsza edycja Epistola... ukazala sie w Rzymie w oficynie Marcelluca Silhera w $1515 \mathrm{r}$. W pól roku pó ni, i 
${ }^{112}$ Ukazała się w Bolonii w 1529 r.

${ }^{113}$ Pierwsze wydanie ukazało się w Krakowie w oficynie Heleny Unglerowej w 1548 r. Oprócz mowy St. Orzechowskiego zawierało także wiersze Jakuba Przyłuskiego: BN sygn. XVI.0.305.

${ }^{114}$ Antologia została następnie kilkakrotnie przedrukowana w Kolonii w latach 1559-1560. ${ }^{115}$ Opublikowane w 1536 r. w bazylejskiej oficynie Andreasa Cratandra.

${ }^{116}$ BUW sygn. Sd.618.21.

${ }^{117}$ BUW sygn. Sd.618.79.

${ }^{118}$ Radcy księcia Bawarii Wilhelma V Pobożnego.

119 Tom pierwszy zadedykowal arcybiskupowi gnieźnieńskiemu Jakubowi Uchańskiemu, tom drugi biskupowi kujawskiemu Mikołajowi Wolskiemu, tom trzeci biskupowi płockiemu Andrzejowi Noskowskiemu, a tom czwarty biskupowi chelmińskiemu Wojciechowi Staroźrebskiemu.

${ }^{120}$ Podobnych przykładów można przytoczyć znacznie więcej. Warto zwrócić uwage na Hieronymusa Commelinusa z Heidelbergu. Był m.in. wydawcą wznowienia Haeliodori Aethiopicorum libri $X$. Druk ukazal się w 1596 r. H. Commelinus zadedykowal go radcy elektora Palatynatu Michaelowi Lingelsheimowi. Z listu dedykacyjnego dowiadujemy się, że do swojego wydania dziela Heliodorusa, dolączyl oryginalny, grecki tekst dzieła. Właśnie tekstu greckiego dotyczyły poprawki wprowadzone przez przyjaciół i współpracowników H. Commelinusa. Poprawili błędy wcześniejszej, bazylejskiej edycji Etiopik, którą wydał J. Herwagen.: BUW sygn. Sd.618.374.

${ }^{121}$ W 1593 r. zob. E XVII, s. 277.

${ }^{122} \mathrm{Ch}$. Plantina z $1575 \mathrm{r}$.

${ }^{123}$ Pod tytulem In Quinti Horatii Flacii...Poemata omnia rerum ac verborum locupletissimus index. Slownik T. Tretera ukazal się wespól z indeksem wybitnego humanisty, wydawcy tekstów klasycznych Henri Estienna II (Stephanusa). Zdb. E XXXI, s. 312-313.

${ }^{124}$ BUW sygn. Sd.54.11.

${ }^{125}$ Wydanie z 1512 r.: BUW sygn. 28.2.3.60.

${ }^{126}$ Ukazało się w oficynie J. Hallera w 1519 r.: BUW sygn. 28.2.3.28.

${ }^{127}$ Ukazało się w oficynie M. Cholinusa: BUW sygn. 28.1.6.15.

${ }^{128}$ BUW sygn. 28.3.2.16.

${ }^{129}$ W Krakowie w Oficynie Łazarzowej w 1582 r.: BUW sygn. 28.3.2.13.

${ }^{130}$ Kraków w 1591 r.

${ }^{131}$ Wittenberga w $1584 \mathrm{r}$.

${ }^{132}$ Np. we Francji wydano Confessio fidei catholicae Christiana St. Hozjusza zarówno w wersji lacińskiej jak i w thumaczeniach na język francuski: Paryż w 1566 i 1579 r.

${ }^{133}$ Dużą popularnością cieszył się w Europie zbiór S. Grynaeusa Novus orbis regionum ac insularum przetlumaczony np. na język holenderski i wydany pt. Die nieuwe werelet der landtschappen w 1563 r. Traktat o obu Sarmacjach M. Miechowity ukazywał się także w thumaczeniu włoskim pt. Historia delle due Sarmatie opublikowanym w Wenecji w 1561, 1562 i 1584 r.

${ }^{134}$ BUW sygn. 28.4.5.23.

${ }^{135}$ BUW sygn. 28.6.11.3ta. 